\title{
REgULATING ADWORDS: Consumer Protection In A MARKeT WHERE THE COMMODITY IS SPEECH
}

\begin{abstract}
Alex W. Cannon*
All current forms of activity tend towards advertising and most exhaust themselves therein. Not necessarily advertising itself, the kind that is produced as such-but the form of advertising, that of a simplified operational mode, vaguely seductive [and] vaguely consensual. ${ }^{1}$
\end{abstract}

\section{INTRODUCTION}

We should be elated, we should be concerned, yet we should not be surprised. Google ${ }^{2}$ can read our minds, tell us what we want to purchase, assist us in fulfilling our most personal and closely guarded desires, further our businesses, update us on current events, make decisions for us, educate us, and keep us healthy. Some consumers "can't think of anything [they] don't search for." tioned sentiments resonate throughout an eight-minute Internet flash video made for the Museum of Media History entitled EPIC: 2014, which predicts that Google will merge with Amazon.com, TiVo, Blogger, and various social networking tools to create the "Google

* J.D. Candidate, 2009, Seton Hall University School of Law. B.F.A., 2003, Webster University. The author wishes to thank Professor Frank Pasquale for his invaluable assistance; his parents for their continued love and support; and his friends in New York, New Jersey, and Atlanta. Finally, the author wishes to thank Larry Page and Sergey Brin for their nonpareil research assistance.

1 JEAn Baudrillard, Absolute Advertising, Ground-Zero Advertising, in Simulacra AND Simulation 87, 87 (Shelia Faria Glaser trans., Univ. of Mich. Press 1994) (1981).

${ }^{2}$ While this Comment primarily concerns Google, Inc., it uses "Google" not only to refer to Google, Inc., but also to search engines in general.

${ }_{3}$ Deborah fallows, Pew Internet \& American life Project, Search Engine

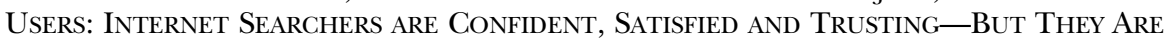
Also UnAwARE AND NAÏVE 7 (Jan. 23, 2005), available at http://www.pewinternet.org /pdfs/PIP_Searchengine_users.pdf (A study of search engine users found that searchers turn to search engines "for need-to-know information [and] for trivia."). 
Grid." In EPIC co-creator Robin Sloan's universe, the Google Grid would be the most efficient information platform ever createdallowing users to effortlessly consume and continuously produce information. ${ }^{5}$ As Sloan voices doubts that the events prophetically depicted in EPIC will ever come to pass, ${ }^{6}$ Google continues to assert its dominance in the search engine market, ${ }^{7}$ expand its corporate apparatus into new ventures, ${ }^{8}$ and increase its capital at an astonishing rate. $^{9}$ The more Google customizes its capabilities and increases its convenience, the greater society's dependence on Google could become. $^{10}$

It is the best of times and it is the worst of times for consumers of all stripes. By simply "googling" a product, the consumer has immediate access to a plethora of commodities made available by online vendors. From locating sneakers to securing mortgages, Google acts as a sophisticated concierge, ${ }^{11}$ or perhaps, more accurately, a sales assistant at a store whose shelf-space is unrestricted by the economic limitations plaguing the brick-and-mortar crowd. ${ }^{12}$ Whether the searcher seeks goods, services, or information, Google makes suggestions and thereby directs the consumer to the most appropriate sup-

\footnotetext{
${ }^{4}$ Robin Sloan, EPIC: 2014 (Museum of Media History 2004), http://epic. makingithappen.co.uk/ (last visited Jan. 13, 2009).

${ }^{5}$ Id.

${ }^{6}$ Masha Gellar, The Demise of the Fourth Estate, iMedia Connection, Feb. 7, 2005, http:/ /imediaconnection.com/content/5020.asp (last visited Jan. 13, 2009).

7 Steve Lohr, The Risks to Google's Rise, N.Y. TIMEs, Oct. 13, 2007, at C1. ("In September [2007,] Google's share of Web searches in the United States was 67 percent....").

${ }^{8}$ Google recently acquired advertising giant DoubleClick for $\$ 3.1$ billion. Press Release, Google, Google to Acquire DoubleClick (Apr. 13, 2007), available at http://www.google.com/intl/en/press/pressrel/doubleclick.html. Not only does this purchase give Google "sole control over the largest database of user information the world has ever known," but it also allows Google to "become the overwhelmingly dominant pipeline for all forms of online advertising." Senators Scrutinize Google's Bid for Ad Firm, N.Y. Times, Sept. 28, 2007, at C4 [hereinafter Google's Bid].

${ }^{9}$ See infra note 41 and accompanying text.

${ }^{10}$ Robin Sloan, Position Paper 1 (2006) (unpublished manuscript, on file with author) (hypothesizing that Google could someday create Google Vote, Google Census, Google FOIA, and Google Redistricting).

${ }^{11}$ Perhaps in the case of Google's sponsored results, Google acts more like a concierge who takes kickbacks from local restaurants in exchange for directing guests to their places of business.

12 See Chris Anderson, The Long-Tail: Why the Future of Business Is Selling LESS OF MORE 1-10 (2006) (explaining how the low cost of reaching consumers transformed the marketplace from a one-size-fits-all model to a collection of decentralized niche markets tailored for specialty consumers).
} 
plier. ${ }^{13}$ However, all this convenience comes at a price: Google's services may be cost-free to the searcher, but the potential implications to the searcher's privacy and autonomy may be drastic. Google catalogues personal information about its users, keeps track of search results, and collects the search logs generated from individual user's queries. ${ }^{14}$ Furthermore, the U.S. government, through either its legislature or its judiciary, is doing little to restrict Google's ability to profit from deceptive or incomplete search results. ${ }^{15}$

This Comment hopes to increase the dialogue surrounding search engine regulation. Starting with the legal assumption that where there is a wrong there should be a remedy, ${ }^{16}$ this Comment asserts that the judicial treatment of Google as a fully protected First Amendment speaker is dangerous precedent. ${ }^{17}$ Google is an advertising machine, and as a publicly traded company its directors are obligated to increase the value of the organization by utilizing every tool at its disposal to get consumers' eyes on ads. ${ }^{18}$ In this respect, Google does not express an opinion in the traditional context of the First Amendment. Rather, by achieving a symbiotic balance between its

${ }^{13}$ Google fulfills its duty via a trade secret algorithm trademarked as PageRank. See Frank Pasquale, Rankings, Reductionism, and Responsibility, 54 CLEV. ST. L. REV. 115, 137 n.96 (2006); Google.com, Technology Overview, http://www.google.com/ corporate/tech.html (last visited Jan. 13, 2009) (describing the PageRank Technology).

${ }^{4}$ See Gonzales v. Google Inc. 234 F.R.D. 674, 688 (N.D. Cal. 2006) (holding that Google must provide the Government with an index of its search results, but that the individual search logs would be duplicative); see also Google.com, Google Privacy Policy, http://www.google.com/intl/en/privacypolicy.html (last visited Jan. 13, 2009) (providing a full description of Google's privacy policies and procedures). While privacy is not the primary concern of this Comment, it is important to note the vast amounts of personal data Google aggregates because, if unchecked, Google could readily abuse its position of power in the marketplace. But see Microsoft v. Google: When Clouds Collide, EcONOMIST, Feb. 7, 2008, at 69-70 [hereinafter Microsoft v. Google].

${ }^{15}$ See, e.g., Andrew Sinclair, Note, Regulation of Paid Listings in Internet Search Engines: A Proposal for FTC Action, 10 B.U. J. SCI. \& TECH. L. 353, 360-62 (2004); see also, Google, Inc. v. American Blind \& Wallpaper Factory, Inc., No. C-03-5340, 2007 U.S. Dist. LEXIS 32450, at*8 (N.D. Cal. Apr. 18, 2007).

${ }^{16}$ See Marbury v. Madison, 5 U.S. 137, 163 (1803) ("The very essence of civil liberty certainly consists in the right of every individual to claim the protection of the laws, whenever he receives an injury."). No doubt Chief Justice Marshall had the following legal maxim in mind: "ubi jus ibi remedium."

17 See Langdon v. Google, Inc., 474 F. Supp. 2d 622, 630 (D. Del. 2007); Search King, Inc. v. Google Tech., Inc., No. CIV-02-1457, 2003 U.S. Dist. LEXIS 27193, at *12-13 (W.D. Okla. May 27, 2003).

${ }^{18}$ See infra note 90 and accompanying text. 
[Vol. 39:291

clients and its users, Google is able to garner massive profits. ${ }^{19}$ Google's corporate interests need to be weighed against societal interests such as informational reliability and informational autonomy. Further, the traditional free-market checks disintegrate in light of Google's rather un-savvy users. ${ }^{20}$ The most visceral danger would be to allow Google, with its ability to tactfully and discretely manipulate consumers, unfettered power to subjectively control access to an important speech market. ${ }^{21}$ Finally, this Comment proposes that the Federal Trade Commission (FTC) would be able to regulate Google's sponsored search results under the commercial speech doctrine.

Conceptualizing Google as a concierge service that generates capital from selling advertising space provides a useful framework for examining the role of the government in protecting consumers, private individuals, and commercial entities from abuse. Part II of this Comment provides a brief history and overview of the law of search. Also, using a recent study by the Pew Internet and American Life Project, ${ }^{22}$ this Comment shows that user expectations are surreptitiously undermined by Google's placement of hits on its results page. Part III compares the solutions proposed by Andrew Sinclair ${ }^{23}$ and Eugene Volokh $^{24}$ and discusses Google's First Amendment limitations. Part IV explains why Google's service is commercial in nature and therefore should be regulated under the commercial speech doctrine. Finally, Part V applies the four-factor test from Central Hudson ${ }^{25}$ and its progeny to Andrew Sinclair's proposal for FTC regulation.

19 See Lohr, supra note 7; Posting of Miguel Helft to Bits Blog-NY Times.com, http://bits.blogs.nytimes.com/2007/10/08/google-shares-top-600/ind ex.html?hp (Oct. 8, 2007, 16:11 EST). Google's “\$144 billion market value tops that of Time Warner, Viacom, CBS, ad agency giant Publicis Groupe and the New York Times Co. combined." Michael Barber, Google: The David or Goliath of the Media World, (2008), http://www.sitewire.net/newsletters/volume/3/issue/4/\#googleplexed (last visited Jan. 13, 2009).

20 See infra Part II.

21 This Comment does not take issue with Google, Inc.'s unofficial corporate motto of "Don't Be Evil." See Lohr, supra note 7. However, judicial acquiescence to the interests of a privately controlled, culturally defining tool presents a unique threat to a democratic society.

${ }^{22}$ FALlows, supra note 3.

23 Sinclair, supra note 15, at 369-73.

${ }^{24}$ Eugene Volokh, Freedom of Speech and Information Privacy: The Troubling Implications of a Right to Stop People From Speaking About You, 52 STAN. L. Rev. 1049 (2000).

${ }^{25}$ Cent. Hudson Gas \& Elec. Corp. v. Pub. Serv. Comm'n, 447 U.S. 557 (1980). 


\section{GENERAL BEWILDERMENT AND THE NEED FOR REGULATION:} SEARCHERS ARE CONFIDENT, UNINFORMED, AND LOYAL

Before the Internet became a ubiquity, the media were dominated by several large entities controlling nearly every aspect of broadcast communication. This figurative, and sometimes literal, monopoly imposed high entry costs for individual speakers as well as corporations who desired to reach consumers. Essentially, major media outlets served as a filter of speech-if the speaker's message was deemed fringe or otherwise unprofitable, then that person's speech was excluded from broadcast and the message would not reach a broad audience. Early commentators predicted that the Internet would "ameliorate the traditional mass-media bottleneck and render moot the policy and legal debate that surround[s] it." ${ }^{26}$ When the majority of Internet users were erudite technophiles, the World Wide Web was a bastion of free speech. ${ }^{27}$ Because every user possessed the requisite navigational knowledge, the Internet seemed poised to fulfill its promise as a techno-libertarian free speech utopia. $^{28}$

But as the saying goes, "[t] he times they are a-changin'." ${ }^{29}$ Today over 1.4 billion people worldwide use the Internet, ${ }^{30}$ with each individual consuming goods and information. In many circumstances, people use message boards, wiki-technology, or HTML to create their own Internet speech. This vast quantity of both Internet users and Internet data presented a conundrum from a social science perspective.

As the sheer density of information available online has skyrocketed, a user's ability to efficiently traverse a decentralized network has

${ }^{26}$ Oren Bracha \& Frank Pasquale, Federal Search Commission? Access, Fairness, and Accountability in the Law of Search, 93 CORNELL L. Rev. 1149, 1150 (2008) (explaining high-cost entry fees).

${ }_{27} I d$. at 1157 (" $[\mathrm{C}]$ ommentators urged courts and policymakers to grant a high degree of protection to Internet speech.”).

${ }_{28}$ See FAllows, supra note 3, at 4 (arguing that the social value of the free speech may have been questionable: "In the earliest days of the Internet and search engines ... two of the most popular search topics were sex and technology.").

${ }^{29}$ Bob Dylan, The Times They are A-Changin', on The Times They are A-Changin' (Columbia Records 1964).

${ }^{30}$ Miniwatts Marketing Group, Internet Usage Statistics (2008), http://www. internetworldstats.com/stats.htm (last visited Jan. 13, 2009) (citing to information published by Nielson Net Ratings) (finding that over seventy-three percent of the North American population is online). 
[Vol. 39:291

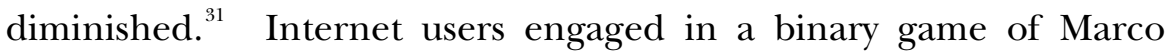
Polo-blindly grasping for material that they could neither sort nor recognize-and the search engines capitalized on this confusion. By providing Internet users with a starting point, search engines greatly increased the utility and social value of the Internet. As a testament to the practicality of search engines, current statistics indicate that " $84 \%$ of Internet users have used search engines" ${ }^{32}$ and that "[o]n any given day, $56 \%$ of those online use search engines." ${ }^{33}$ Of all the search engine companies, no single provider has been as successful as Google. ${ }^{34}$ At the current pace, nearly 400 million people per month start each Internet visit on Google.com. ${ }^{35}$ Google commands sixtyfour percent of all searches performed by Internet users, ${ }^{36}$ as compared to its closest competitor, Yahoo.com, which only maintains thirteen percent of the market share. ${ }^{37}$ Like the broadcasting behemoths of the bygone era, Google is the primary bottleneck of our current informational age. ${ }^{38}$ As professors Bracha and Pasquale have stated, "The specter of control . . . over critical bottlenecks of informational flow threatens the openness and diversity of the Internet as a system of public expression."

Google has the power to exclude content or make an overnight cultural sensation. $^{39}$ Its tastemaker status is solidified by its simplicity, and Google is widely revered for being the largest indexer of Internet content, currently listing over eight billion web pages. ${ }^{40}$ In recognition of Google's impressive societal leverage, businesses reward it with tremendous advertising revenue; in 2006 Google generated $\$ 10.6$ bil-

${ }^{31}$ For an excellent discussion of the rise of search engine technology and its effect on society, see Urs Gasser, Regulating Search Engines: Taking Stock and Looking Ahead, 8 YAle J.L. \& TECH. 201 (2006).

${ }^{32}$ FAllows, Summary of Findings, in supra note 3, at i. "Some $84 \%$ of adult Internet users ... have used search engines to help them find information on the Web. Only the act of sending and receiving email . . . eclipses searching in popularity . ..." Id. at 1 .

Id. ("American Internet users pose about 4 billion queries per month.").

See Lohr, supra note 7.

35 See Helft, supra note 19.

36 Microsoft v. Google, supra note 14, at 69.

${ }^{37} I d$.

38 Bracha \& Pasquale, supra note 26, at 1172.

39 See, e.g., Video: Tay Zonday, Chocolate Rain (April 22, 2007), http://www. youtube.com/watch?v=EwTZ2xpQwpA (as of January 13, 2009, 33,181,166 people, roughly the population of Canada, had viewed Chocolate Rain).

Fallows, supra note 3, at 1 . 
lion in advertising fees, representing a seventy-three percent increase as compared to $2005 .^{41}$

A brief discussion of legislative policy will help frame the issue of consumer protection under the Google regime. In 1996, Congress passed the Telecommunications Act, ${ }^{42}$ recognizing that the "World Wide Web [is] a valuable source of information and medium for the exchange of ideas, the commercialization of Internet navigation though private control of portals, gateways, browsers and search engines poses new problems." ${ }^{43}$ Congress drafted the Telecommunications Act with the intent to create a competitive market in information technology by removing barriers to marketplace entry. ${ }^{44}$ Ironically, the legislative goal of consumer protection ${ }^{45}$ missed the mark, and as predicted by Walter G. Bolter, the Telecommunications Act and its subsequent deregulation of the telecom markets did not facilitate new entry but rather "permitted the aggregation[] of economic power." ${ }^{46}$ A glance at the daily papers reveals that current market conditions continue to teeter between monopoly and competition. A non-inclusive list of recent telecom mergers suggests that the balance may soon tip in favor of monopoly: AT\&T recently merged with Media One; AOL merged with Netscape; Lycos merged with USA Networks; US West and Qwest recently became one; and Google recently acquired YouTube and added DoubleClick to its advertising arsenal. ${ }^{47}$ At least two commentators have suggested that the market conditions in the years immediately following the Telecommunications Act indicated a monumental policy failure. ${ }^{48}$

Where does this leave consumers? Does the average consumer understand the broad ramifications for informational reliability posed by the aggregation and centralization of the most culturally defining informational nexus since the Library of Alexandria? Do con-

41 See Andrew Goodman, Winning Results with Google AdWords 21 (2d ed. 2008).

36 Pub. L. No. 104-104, 110 Stat. 56 (1996).

43 Jan H. Samoriski, Private Spaces and Public Interests: Internet Navigation, Commercialism and the Fleecing of Democracy, 5 COMM. L. \& POL'Y 93, 94 (2000).

${ }^{44} I d$.

45 Congress enacted 47 U.S.C. $\$ 253$ to "ensure the continued quality of telecommunications services, and [to] safeguard the rights of consumers." H.R. REP. No. 104-458, at 126 (1996).

${ }^{46}$ Walter G. Bolter, Trends in Communication: A Market and Policy Perspective, in TEleCOMmunications: COMmon CARRIERS IN A COMPETITIVE ERA 87, 91 (1983).

${ }^{47}$ See supra note 8 and accompanying text.

48 Jeffery A. Eisenach \& Randolph J. May, Communications Deregulation and FCC Reform: Finishing the Job, in Communications DeRegulation AND FCC REForm 2, 2 (Jeffery A. Eisenach \& Randolph J. May eds., 2001). 
sumers expect Google to behave as an objective reference librarian and, if so, what are the implications of Google's AdWords ${ }^{49}$ program? Ultimately, the question for policymakers is whether the government should explicitly protect consumers' expectations of objectivity in the online domain.

A recent study undertaken by the Pew Internet \& American Life Project ${ }^{50}$ demonstrates that the vast majority of searchers are confident in their ability to retrieve relevant search results. ${ }^{51}$ On the one hand, one could assume that search engines are performing with a high level of reliability and accuracy; such an assumption is not inconsistent with Google's high market share. ${ }^{52}$ Perhaps, Google maintains its market power because users are genuinely satisfied with the search results they receive. However, a closer examination of empirical data indicates that the majority of users lack a sufficient understanding of search engine practices: ${ }^{53}$ One of every six search engine users are unable to distinguish between sponsored results and organic results. ${ }^{54}$ Furthermore, thirty-three percent of search engine users who think that search engine results are fair and unbiased are completely unaware of the distinction between results that are paid for and those that are not. ${ }^{55}$ A comparison of search engine results to a television broadcast, where every consumer can readily distinguish "between TV's regular programming and its infomercials," strongly suggests that the searcher's sanguinity is inappropriate. This leaves open the question of whether Google's marketing minds, which divine search engine practices, could actively manipulate consumers by instilling a false sense of security into their psyches.

49 AdWords is Google's primary source of revenue. Ebay to Resume Advertising on Google but Cuts Frequency, N.Y. Times, June 23, 2007, at C9. It allows a business to purchase specific keywords so that when a searcher enters the relevant keyword, the business's webpage appears as a sponsored result. Google.com, Google AdWords, https:/ /adwords.google.com (last visited Jan. 13, 2009).

FALlows, supra note 3.

${ }^{51} I d$. at 8 ("Some $92 \%$ of those who use search engines say they are confident about their searching abilities.").

${ }^{52}$ Lohr, supra note 7.

53 FALlOwS, supra note 3, at 16-20.

${ }^{54} I d$. at 17. Sponsored results are the consequence of Google accepting payment for placement on their results page. Generally sponsored results appear at the top and on the right-hand-side of the results page. Organic results are the hits that are generated by Google's complicated search algorithm, are not paid for, and appear in the center of the results page.

${ }^{55} I d$. at 15.

${ }^{56}$ FALlows, Summary of Findings, in supra note 3, at ii. 
In 2001, Consumer Alert, a now defunct non-profit consumer protection agency, filed a complaint with the FTC alleging that search engines were behaving fraudulently. ${ }^{57}$ Consumer Alert stated that search engines, instead of simply relying upon their respective algorithms, were intermingling sponsored results with objective results and not providing adequate differentiation information that would allow consumers to distinguish the advertisement from the organic. $^{58}$ The FTC agreed. Upon Consumer Alert's request, the FTC investigated and responded not by demanding that search results be clearer but by drafting a letter to search engine companies requesting that "the use of paid inclusion [be] clearly and conspicuously explained and disclosed." ${ }^{59}$ Because of the FTC's perfunctory regulatory effort, it is unsurprising that users are still generally unable to distinguish between the two. ${ }^{60}$

As if consumers were not already David to Google's Goliath, another more psychologically subtle issue compounds the user confusion problem: brand loyalty. In NO LOGO: TAKING AIM AT THE BRAND BULLIES, Naomi Klein suggests that the grail of modern marketing is the inducement of brand loyalty. ${ }^{61}$ In her view, corporate marketers begin conditioning consumers' minds when they are young. Their mission is as multifarious in design as it is easy to execute-to create a loyal consumer for life. ${ }^{62}$ While this scenario may resonate with esoteric images of a gothic horror novel, a moment of personal reflec-

${ }^{57}$ Letter from Heather Hippsley, Acting Associate Director, Division of Advertising Practices, Federal Trade Commission, to Gary Ruskin, Executive Director, Consumer Alert (June 27, 2002), available at http://www.ftc.gov/os/closings/staff/ commercialalertletter.shtm.

${ }^{58} I d$.

${ }^{59}$ Letter From Heather Hippsley, Acting Associate Director, Division of Advertising Practices, Federal Trade Commission, to Search Engine Companies (Jun. 27, 2002), available at http://www.ftc.gov/os/closings/staff/commercialalertattatch. shtm.

${ }^{60}$ FALLOws, supra note 3, at 17. In the years following the FTC's Letter to Search Engine Companies and their general compliance with the FTC's proposals, sixty-two percent of searchers are still unable to distinguish between sponsored and organic results. Id.

${ }^{61}$ NaOmi Klein, No Logo: TAking Aim At the Brand Bullies 4-61 (2002). In a nutshell, Klein argues that consumers make brand choices based on familiarity and "loyalty." In this respect, most consumers whose grade schools had Coke machines are Coca-Cola consumers. She therefore argues that corporations are aware of this phenomenon and focus their marketing revenue towards creating brand loyalty by asserting their corporate presence into disparate cultural areas. See also Ellen P. Goodman, Stealth Marketing and Editorial Integrity, 85 Tex. L. Rev. 83, 89 (2006) (describing the branding process as embedding promotional material into media that otherwise appears to be independent content).

62 KLEIN, supra note 61, at 59-60. 
[Vol. 39:291

tion reveals the premise's veracity. Moreover, it is difficult to break the brand habit; Klein argues that the majority of daily consumer decisions, such as which peanut butter to purchase or, yes, which search engine to use, are dictated by addiction to a specific brand. ${ }^{63}$

It is reasonable to assume that Google intended to and succeeded in creating a "brand." Consumers no longer "search" for information on the Internet, they "google" it. ${ }^{64}$ Through the use of clever marketing coupled with an aesthetically pleasing user interface, Google triumphed in creating a lasting, powerful brand. This could account for the fact that younger users, those who literally grew up on the Internet, are more (troublingly) confident in and more (brazenly) loyal to their personal preference in search engines. ${ }^{65}$ (Most adult users tend to favor, and consistently use, only one or two search engines. $)^{66}$ This loyalty is most likely attributed to mere devotion to an ideal as opposed to the reliability of the search results. Google's users may as well be describing an Italian sports car when they say that they prefer Google over its competitors because it is "clean" and "fast." 67

Google's users prefer Google not because of the objectivity of results, but because Google's product is the Internet equivalent to the shiniest bicycle in the store. One savvy user has troublingly responded that "I use [Google] almost exclusively because it is fast and accurate. I go directly to vendor sites [from the search results page]

${ }^{63}$ Id. at 90 .

${ }^{64}$ See Frank Ahrens, goo.gle (goo'-gul), WASH. Post, Jul. 7, 2006, at D1 (stating that as of July 6, 2007, the editors of Merriam-Webster's Collegiate Dictionary added the transitive verb "to google" into the American lexicon). For a discussion of Google, Inc.'s fear that the verb "to google" will (as is already the case) refer to Internet searches generally and not just to searches performed at Google.com, see Frank Ahrens, So Google Is No Brand X, but What Is 'Genericide'?, WASH. POST, Aug. 6, 2006, at D1.

${ }^{65}$ FAllows, supra note 3, at 23.

66 See id. at 13 (stating that " $44 \%$ of searchers say they regularly use a single search engine, while most of the rest, $48 \%$, will use just two or three"). It is important to compare this figure with the fact that Google currently retains sixty-seven percent of the search engine market. Lohr, supra note 7. These numbers suggest a decidedly large percentage of Internet search engine users only use Google. If there are 1.2 billion people online everyday, and fifty-six percent use the search engine everyday, then it is reasonable to assume that sixty-seven percent of those searching will use Google. Finally, forty-four percent of all regular search engine users are loyal to only one provider. FALlows, supra note 3, at 23. Therefore, as a rough estimate, nearly 200 million search engine users are completely loyal to Google.com. See FALlOWS, Summary of Findings, in supra note 3, at i; Lohr, supra note 7; Miniwatts Marketing Group, supra note 30.

${ }^{67}$ FAllows, supra note 3, at 14. 
when I have that option." ${ }^{68}$ While users also claim that they require objectivity, and that they would stop using a specific search engine if it used deceptive advertising practices, ${ }^{69}$ empirical data strongly suggest that users are too bewildered by and loyal to their search engine brand of choice to adequately impose an economic market threat to search engine companies. In short, so long as Google continues to deliver relevant results, then users will continue to maintain their loyalty.

At this point, it is necessary to fully illuminate a distinction that will carry throughout the remainder of this Comment: there is a subtle but crucial distinction between "accurate" search results and "relevant" search results. "Accuracy," the more restrictive of the two words, is defined as "the condition or quality of being true, correct, or exact; freedom from error or defect; precision or exactness." ${ }^{70}$ By contrast, "relevancy" is defined as the condition of "bearing upon or being connected with the matter at hand; pertinent." search engine provides an "accurate" result, it is behaving in a purely objective manner, one that is akin to the factual rigor consumers expect from quality newspaper reporting. On the other hand, a "relevant" search result need only be "connected" to the query, therefore allowing the search engine to subjectively modify the results pagethe clever placement of advertisements, for example.

For a marketing megalodon such as Google, which tracks the consumption habits of its users though various electronic means, it will not prove difficult to proffer "relevant" results to a naive searcher base: in fact, AdWords results are by their very nature simply relevant. Perhaps Google could maintain its market position by providing and placing relevant advertising. It is far more economically onerous for Google to provide users with highly accurate results. It is helpful to envision two concentric circles, the interior one labeled "accurate" and the exterior one labeled "relevant." Using this paradigm and available data, it is likely that any market response aimed at Google will only occur as the results approach the dubiously relevant. To ameliorate the market pressure, Google merely needs to ensure that its search results fall somewhere short of the margins of relevancy,

Id.

${ }^{69} I d$. at 20 ("Some $45 \%$ of searchers said they would stop using a search engine if they didn't make it clear that some results were paid or sponsored.").

70 RANDOM HOUSE WEBSTER's UNABRIDGED DictionARY 14 (2d ed. 1998) [hereinafter WEBSTER's].

${ }^{71} \quad I d$. at 1628 . 
but it need not ensure that the results are squarely within the more restrictive confines of accuracy.

Thus, for Google to maintain its market share it need only provide users with relevant results because users, concerned primarily with aesthetics and relevancy, are unaware of Google's slight of hand. These naive users will probably not abandon Google because they are too loyal to their brand and lack the capacity to distinguish relevancy from accuracy. Provided that Google continues to strive for relevancy in their sponsored results and advertising, it will reinforce both its market share and its users' loyalty. ${ }^{72}$ What can the law do to protect search engine users? Given the ironic failure of the Telecommunications Act of 1996, and the court system's alacrity to overprotect search results, Google could substitute relevancy for accuracy without consequence from either the economic markets or the legal community. The threat posed by under-regulation is twofold: first is the issue of consumer protection; second is the threat that unregulated search engines, as information bottlenecks, may pose to our contemporary version of the Library of Alexandria. ${ }^{73}$

\section{FTC REGULATION AND FIRST AMENDMENT ABSOLUTISM: OPEN DOORS AND GIANT HURDLES}

\section{A. Andrew Sinclair Proposes FTC Regulation of Google}

Andrew Sinclair was one of the earliest scholars to confront the issue of whether search engines should be regulated by the federal government. $^{74}$ Sinclair proposed that two policy goals would be ad-

72 See Sinclair, supra note 15, at 359 (citing CONSUmer WebWATCH, A MatTer of TRUST: WHAT USERS WANT FROM WEBSITES 17, http://www.consumerwebwatch. org/pdfs/a-matter-of-trust.pdf) (last visited Jan. 13, 2009) (“[C]onsumers . . . [are] unaware that they are not getting the most relevant search results.").

${ }^{73}$ The bigger they are the harder they fall.

74 Sinclair, supra note 15, at 360-61. Sinclair, perhaps ignoring the flaws of the Telecommunications Act of 1996, stated that the Federal Government, and not the states, is positioned to regulate the Internet because the Internet is part of interstate commerce and therefore "demands consistent treatment that can only be achieved by federal regulation." Id. at 360 . However, an examination of the Telecommunications Act reveals that the Congress intended telecom regulation to occur at the state level provided the regulation is "competitively neutral." See H.R. REP. No. 104-458 at 126. The neutrality requirement is perhaps a uniformity requirement, as it would be difficult to conceptualize a varied regulatory scheme that would not run afoul of the dormant commerce clause by placing an undue burden on interstate commerce. See, e.g., Pike v. Bruce Church, Inc., 397 U.S. 137, 146 (1970) (holding that Arizona's interest in protecting its businesses and consumers from deceptive packaging was not substantial enough to justify the burden imposed on interstate commerce). 
vanced by federal regulation of search engine results: (1) that regulation of deceptive practices would increase the searcher's ability to locate the information for which he is looking; ${ }^{75}$ and (2) that regulation would provide the searcher with a remedy for deceptive search engine practices. $^{76}$ In order to achieve the aforementioned policy goals, Sinclair reasoned that either the Federal Communications Commission (FCC) or the FTC could, under their statutorily granted rulemaking authority, promulgate specific rules to protect consumers by requiring search engines to distinguish the sponsored results from the organic results-the relevant from the accurate. ${ }^{77}$

Sinclair identified the FTC as the appropriate regulatory body. Because the FTC has already asserted authority over analogous forms of advertising media, ${ }^{78}$ it is the best equipped to manage the problem of deceptive advertising practices by search engine companies. Under section 5 of the Federal Trade Commission Act, Sinclair proposes that the FTC require (1) that sponsored results "Contain an Identifying Phrase such as "Paid Listing,",79 (2) that "Paid Listings Should be Spatially and Colorfully Separated from Unpaid Listings," ${ }^{80}$ and (3) that "Paid Listings Should Have At Least One Other Identifiable Difference" from the organic results. ${ }^{81}$ Sinclair's hydra-headed remedy actually advances three policy goals-that forcing search engines to clearly disclose sponsorship will decrease customer confusion, increase the relevance of search engine results, and provide an injured party with a remedy.

Ultimately, Sinclair urged that the FTC take adjudicative action under his proposed rules to reduce any confusion that may arise among search engines as to compliance. By so doing, the FTC will take a "strict stance against deceptive advertising online to match that against deceptive advertising on television and in print." ${ }^{" 2}$ However, one exceptionally powerful principle obstructs Sinclair's proposed

75 See Sinclair, supra note 15 , at 375 .

${ }^{76} I d$.

${ }_{77} I d$. at $361-64$.

78 Id. at 360-63. Specifically, Sinclair argues that the FTC has authority under section 5 of the Federal Trade Commission Act, 15 U.S.C. $\$ \S 41-58$ (2000), to regulate deceptive acts in which "the consumer is likely to suffer injury from a material misrepresentation.” Id. (citing In re Nat'l Media Corp., Inc., 116 F.T.C. 549, 559 (1993) (consent order)).

${ }^{79}$ Id. at 369.

${ }^{80}$ Sinclair, supra note 15 , at 370 .

81 Id. at 371 (This rule is intended to provide room for "search engine creativity" while reinforcing the "distinction between paid and unpaid links.").

${ }^{82} I d$. at 378. 
[Vol. 39:291

FTC action: the First Amendment. Sinclair addressed the free speech hurdle quickly by stating the likelihood that courts would consider regulation of search engine results under the commercial speech doctrine as outlined in Central Hudson. ${ }^{83}$ In light of recent scholarship, ${ }^{84}$ and the latest judicial decisions attempting to define the freespeech component of search law, ${ }^{85}$ Sinclair's proposal requires a more thorough examination.

\section{B. Problematic Precedent and First Amendment Absolutism}

The threshold obstacle to FTC regulation of search engines' sponsored results is determining whether Hurley v. Irish-American Gay, Lesbian and Bisexual Group of Boston, ${ }^{86}$ and its reaffirmation of the right to be free from compelled speech, prohibits Sinclair's proposed regulation. In Hurley, the Supreme Court of the United States faced the issue of "whether Massachusetts may require private citizens who organize a parade to include among the marchers a group imparting a message the organizers do not wish to convey." ${ }^{87}$ The issue came before the Court on a petition for certiorari by Hurley and the private organizers of the parade, the South Boston Allied War Veterans Council (Council). In 1992, the respondents-members of the Boston Area Gay, Lesbian, and Bi-Sexual Organization (GLIB) - applied to take part in that year's parade. ${ }^{88}$ After the Council rejected GLIB's application, GLIB obtained a state court order requiring the Council to permit GLIB's members to march. ${ }^{89}$ In 1993, GLIB again sought the Council's permission to march in the parade, and the Council again denied GLIB's request. ${ }^{90}$ GLIB filed suit in state court "alleging violations of the State and Federal Constitutions and of the state public accommodations law." ${ }^{91}$ The state trial court ruled in favor of

${ }^{83}$ Id. at 363-64 (acknowledging that the "First Amendment may offer some hurdles to the regulation of paid search engine listings").

${ }^{84}$ See Tom Bennigson, Nike Revisited: Can Commercial Corporations Engage in NonCommercial Speech, 39 ConN. L. REv. 379 (2006); Goodman, supra note 61; Volokh, supra note 24.

${ }^{85}$ See Langdon v. Google, Inc., 474 F. Supp. 2d 622, 630 (D. Del. 2007); Search King, Inc. v. Google Tech., Inc., No. CIV-02-1457, 2003 U.S. Dist. LEXIS 27193 (W.D. Okla. May 27, 2003).

${ }^{86}$ Hurley v. Irish-American Gay, Lesbian and Bisexual Group of Boston, 515 U.S. 557 (1995).

${ }^{87} I d$. at 559 .

${ }^{88} I d$. at 561 .

${ }^{89} \quad I d$.

${ }^{90} \mathrm{Id}$.

${ }^{91} I d$. at 561. For the full text of Massachusetts's public accommodation law, see MASS. GEN. LAWS ch. 272, § 92A (2007). 
GLIB and held that a parade falls within the definition of a public accommodation. $^{92}$ In doing so, the Massachusetts court disregarded the Council's argument that GLIB's inclusion in the parade violated the Council's First Amendment rights. ${ }^{93}$ The Council subsequently appealed the trial court's determination to the Supreme Judicial Court of Massachusetts, which affirmed the lower court's decision as not clearly erroneous. ${ }^{94}$ The state supreme court held that there was no expressive purpose in the parade..$^{95}$ Upon an unfavorable verdict in the state supreme court, the Council petitioned for certiorari in the Supreme Court of the United States. ${ }^{96}$

GLIB's first argument urged the Court to find that a parade does not contain First Amendment speech. Writing for a unanimous Court, Justice Souter declared that the Massachusetts Supreme Judicial Court wrongly decided that a parade contains no expressive conduct. ${ }^{97}$ Souter stated that a parade indicates that the marchers "are making some sort of collective point, not just to each other but to bystanders along the way." ${ }^{98}$ After determining that the Council's parade contained sufficient expression to warrant First Amendment protection, Justice Souter acknowledged that a parade need not have a "succinctly articulable message" tection, and that inherent within the liberty provided by the First Amendment is the freedom to abstain from speaking. ${ }^{100}$ The Court upheld the autonomy of the speaker by stating that whatever the reason for the Council's exclusion of GLIB, "it boils down to the choice of a speaker not to propound a particular point of view, and that choice is presumed to lie beyond the government's power to control." 101

Turning next to the argument that Massachusetts's public accommodation law prohibited the Council's exclusionary action, GLIB

${ }^{92}$ Hurley, 515 U.S. at 561.

${ }^{93} I d$. at 563 .

${ }^{94} I d$. at 564.

95 Irish-American Gay, Lesbian and Bisexual Group of Boston v. Boston, 636 N.E.2d 1293, 1295-98 (Mass. 1994).

${ }^{96}$ Hurley, 515 U.S. at 557

97 Id.at 579.

98 Id. at 568 .

${ }^{99} I d$. at 569

${ }^{100}$ Id. (citing West Virginia Bd. of Ed. v. Barnette, 319 U.S. 624, 632 (1943)); see also Wooley v. Maynard, 430 U.S. 705, 717 (1977) (holding that the First Amendment protects the decisions of private individuals not to display "Live Free or Die" on their state issued license plate).

101 Hurley, 515 U.S. at 575. 
[Vol. 39:291

urged that "any tension between [the no compelled speech rule] and the Massachusetts law falls short of unconstitutionality." 102 In support of its argument, GLIB cited to Turner Broadcasting System, Inc. $v$. $F C C,{ }^{103}$ in which the United States Supreme Court refused to apply strict scrutiny ${ }^{104}$ in order to ameliorate "[the] potential for abuse of [a] private power over a central avenue of communication." ${ }^{105}$ In Turner Broadcasting, Turner, the petitioner, asserted that the First Amendment right to abstain from speech protected the company from government regulation of its broadcast pursuant to the Television Consumer Protection Act of 1992. ${ }^{106}$ The Court reasoned that the FCC regulation should be analyzed under Congress's power to "correct market failure in a market whose commodity is speech" ${ }^{107}$ and that congressional exercise of such power is not unconstitutional so long as the regulation is content neutral. ${ }^{108}$ Because the requirement to carry local broadcasting merely limited the ability of Turner to compete in economic markets, ${ }^{109}$ because it did not favor one form of speech over another, ${ }^{110}$ and because there was an important governmental interest, ${ }^{111}$ the Court analyzed whether the regulation was sufficiently tailored. ${ }^{112}$ However, there was a "paucity of evidence in-

102 Id.

103 Turner Broad. Sys., Inc. v. FCC, 512 U.S. 622 (1994) (plurality opinion).

104 Id. at 659-63.

105 Id. at 657.

106 Pub. L. No. 102-385, 106 Stat. 1460 (1992). The act required cable companies, inter alia, to include in their transmissions local network broadcasts and qualified educational programming. Turner Broad., 512 U.S. at 630-31.

107 Turner Broad., 512 U.S. at 640 (citing Associated Press v. United States, 316 U.S. $1(1945))$.

108 Id. at $642-43$.

109 Id. at 637. Turner Broadcasting, however, noted that "dysfunction or failure in a speech market, without more, is not sufficient to shield a speech regulation from the First Amendment standards applicable to nonbroadcast media." Id. at 640. Yet, as to Google and it enormous market share, there is more than a mere dysfunction in the speech market, there is actual customer confusion as to the nature of the results. See infra notes 217-19 and accompanying text.

110 Specifically, the Court stated that "given cable's long history of serving as a conduit for broadcast signals, there appears little risk that cable viewers would assume that the broadcast stations carried on a cable system convey ideas or messages endorsed by the cable operator." Id at 656 .

${ }^{111}$ Id. at 662-63 (identifying three important governmental interests: "(1) preserving the benefits of free, over-the-air local broadcast television, (2) promoting the widespread dissemination of information for a multiplicity of sources, and (3) promoting fair competition in the market for television programming”). Id. at 662.

${ }^{112}$ Id. at 664-68. 
dicating that broadcast television is in jeopardy,"113 and the Court could not determine if the regulation restricted "substantially more speech than necessary" to further its goals. ${ }^{114}$ Ultimately, the Court reversed the trial court's grant of summary judgment for the government and remanded the case back to the district court. ${ }^{115}$

Turning back to the Hurley decision, the Court rejected GLIB's argument that Turner Broadcasting mandates the application of intermediate scrutiny to the trial court's decision that GLIB must be allowed to march in the parade. ${ }^{116}$ The Court distinguished Turner Broadcasting on several grounds: (1) because it is likely that viewers would assume that the Council endorsed GLIB's message; ${ }^{117}$ (2) because a cable operator is a "monopolistic opportunity to shut out some speakers"; ${ }^{118}$ and (3) GLIB could have applied for its own parade permit, and thus it failed to show that the Council had the "capacity to 'silence the voice of competing speakers,' as cable operators do." 119 Therefore, the Court applied strict scrutiny, stated that there was an alternative venue for GLIB's speech, and found that forcing the Council to allow GLIB's participation in the parade infringed on the Council's First Amendment right to autonomy of speech. ${ }^{120}$

Because the most logical assumption is that the FTC would use its authority to protect consumers from injury due to deceptive advertising practices, Google would likely characterize its sponsored results as speech protected by the First Amendment, therefore seeking to have the court scrutinize the FTC regulation pursuant to Hurley. In order to assert a First Amendment challenge to FTC regulation, Google would, at a threshold level, need to show that its search results are entitled to full First Amendment free speech guarantees. However, it is unlikely that Google would receive full First Amendment protection. First, Hurley is distinguishable from the current situation with Google because a parade fundamentally differs from a website. The former makes "some sort of collective point" ${ }^{121}$ because

\footnotetext{
113 Turner Broadcasting, at 667. Further, it is likely that the government would be able to show that the search engine market, and therefore the Internet, is in jeopardy.

Turner Broad., 512 U.S. at 668 (citing Ward v. Rock Against Racism, 491 U.S. 781, 799 (1989)).

${ }_{115} I d$.

116 Hurley, 515 U.S. at 258-59.

${ }^{117} I d$. at 576-77.

$118 \quad I d$. at 577 .

119 Id. at 578 (citing Turner Broad., 512 U.S. at 656).

${ }^{120} I d$. at 580-81.

121 Id. at 568 .
} 
[Vol. 39:291

each of the marchers participate with a common goal-in the case of a St. Patrick's day parade, they speak not only as individuals but also as a group possessing a common theme (their love for green beer?). Google's search results have no such theme or unity of purpose; in fact, those who participate in AdWords foster no such group purpose, to the contrary, they all desire to standout as individual businesses, devoid of affiliation with a collective, free-speech goal or opinion. In short, Google's AdWords program, in its entirety, fails to capture a "succinctly articulable message." 122 Thus, assuming that the contours of any FTC disclosure rule are content neutral, the principles articulated in Hurley do not prohibit the disclosure as compelled speech. ${ }^{123}$

Because the purpose of this Comment is to advocate on behalf of consumer protection and potential regulation, an examination of a recent federal court's treatment of Google as a speaker is also important. Recently, in Langdon v. Google, Inc., the United States District Court for the District of Delaware, granting Google's summary judgment motion, extended robust First Amendment protection to Google. ${ }^{124}$ Langdon, the owner of two Internet websites, www.NCJusticeFraud.com and www.ChinaIsEvil.com, ${ }^{125}$ alleged that Google refused to allow advertisements for both websites and sought damages and injunctive relief. ${ }^{126}$ Further, Langdon argued that "Google gave a fraudulent excuse for not running the [advertisements], and that the reasons for refusal do not appear on [Google's] website or in its ad content policy." ${ }^{127}$ In this respect, Langdon claimed that Google's refusals violated his rights under the First and Fourteenth Amendments. ${ }^{128}$ More specifically, he averred that the "rejection or acceptance of ads is based upon whether the political viewpoint of the ad and the related website agree with those of Google's executives and employees." ${ }^{129}$ Finally, he "allege[d] that he ha[d] no viable alternative other than to advertise on Defendants'

${ }^{122}$ Hurley, 515 U.S. at 569. The only conceivable collective point AdWord participants are possibly making is purely for the purposes of inducing a commercial transaction, which favors treating the speech, in the collective, pursuant to the commercial speech doctrine. Infra note 152 and accompanying text.

${ }^{123}$ Hurley, 515 U.S. at 642-43.

124 Langdon v. Google, Inc, 474 F. Supp. 2d 622 (D. Del. 2007).

${ }^{125} I d$. at 626.

${ }^{126} I d$. at 627 .

127 Id. at 626.

${ }^{128} I d$.

129 Id. at 626. Langdon also alleged that Google's de-listing of the NCJustice website "hurt his rankings with other search engines," and that Google's current policy of allowing China to censor Google's search results "does not allow advertisement critical of the Chinese government." Id. at 627. 
search engines." ${ }^{130}$ After a discussion of various procedural and pleading issues raised by the defendants arising from the plaintiff's pro se status, ${ }^{131}$ the district court analyzed the defendants' First Amendment Rights. ${ }^{132}$

In its defense, Google argued that granting Langdon injunctive "relief would compel [it] to speak in a manner deemed appropriate by Plaintiff and would prevent [it] from speaking in ways that Plaintiff dislikes." ${ }^{133}$ Ultimately, the court agreed with Google that its First Amendment rights precluded the relief the plaintiff sought. ${ }^{134}$ However, instead of narrowly limiting its holding to the facts of the current case, the district court extended remarkably broad constitutional protection to Google. Essentially, the court granted Google the same First Amendment status as newspaper editors. ${ }^{135}$ By characterizing Google's activities as that of a newspaper editor, the district court shielded Google from all liability stemming from its so-called editorial decisions. ${ }^{136}$

The district court did not need to extend such broad constitutional protection to Google's advertising and search results. The court found adequate justification for Google's action pursuant to the Communications Decency Act (CDA), ${ }^{137}$ which "provides [Google] immunity from suit from claims grounded upon their exer-

${ }^{130}$ Langdon, 474 F. Supp. 2d at 627.

131 Id. at $625-29$.

132 Id. at 629 .

133 Id.

134 Id. at 634 .

135 See, e.g., Miami Herald Publ'g Co. v. Tornillo, 418 U.S. 241, 256 (1974) (holding that a state statute requiring newspapers to present a right of response to political candidates violated the First Amendment).

${ }^{136}$ This is not the only case in which Google sought to classify itself as a speaker with a First Amendment opinion. In Search King, Google argued that de-listing the plaintiff's customer's webpage was an act shielded from tort liability under the First Amendment because it was per se lawful. Search King, Inc. v. Google Tech. Inc., No. CIV-01-1457-M, 2003 U.S. Dist. LEXIS 27193, at*9 (W.D. Okla. May 27, 2003). The Search King court determined that Google's organic search results represented an opinion of relevance based on keywords. Id. at *11. Therefore, even if Google acted maliciously and willfully in the de-listing of the webpages, the plaintiff was afforded no remedy due to freedom of speech. Id. at $* 13$. However, Google does not always wish to style itself as a subjective speaker. In Google, Inc. v. American Blind \& Wallpaper Factory, Inc., No. C-03-5340, 2007 U.S. Dist. LEXIS 32450, at $* 8$ (N.D. Cal. Apr. 18, 2007), the plaintiff sued Google alleging that Google committed trademark infringement. Google claimed that its AdWords program is completely objective, and that it is therefore at the mercy of the consumer who purchased the specific keywords. Id. at *9 n.6. In short, it appears that Google seeks to inconsistently characterize itself when it comes to avoiding liability.

137 The Communications Decency Act of 1996, 47 U.S.C. $\$ 230$ (c) (2) (A) (2000). 
[Vol. 39:291

cise of editorial discretion over Internet content and editorial decisions regarding screening and deletion of content from their services" 138 regardless of whether the material is constitutionally protected. ${ }^{139}$ The district court determined that based on the complaint, the plaintiff sought to hold Google liable for actions relating to the "monitoring, screening and deletion of content from their network" and that based on applicable case law, ${ }^{140}$ such actions are immunized under section 230 of the CDA. ${ }^{141}$

The plaintiff's final relevant argument was a claim under 28 U.S.C. $§ 1983$, alleging that Google violated the plaintiff's First Amendment rights by de-listing the plaintiff's websites. ${ }^{142}$ Because the plaintiff could not establish that Google was a government actor, ${ }^{143}$ because the court determined that Google was not a public forum, ${ }^{144}$ and because the plaintiff had alternative venues for speech, ${ }^{145}$ Google was not liable under section $1983 .{ }^{146}$

While it seems that Google possesses a strong constitutional argument against government regulation of its search results, even commentators who are staunch advocates for First Amendment absolutism would probably not argue against FTC regulation of Google's sponsored results. For example, Professor Eugene Volokh argues that government regulation and limitations on people's ability to disseminate information about a private individual are generally im-

138 Langdon, 474 F. Supp. 2d at 630.

13947 U.S.C. $\$ 230$ (c) (2) (A).

${ }^{140}$ Ezra v. America Online, Inc., 206 F.3d 980, 986 (10th Cir. 2000).

141 Langdon, 474 F. Supp. 2d at 630 ("Section 230 provides Google . . . immunity for their editorial decisions regarding screening and deletion from their network.").

${ }^{142} I d$. at 632 .

143 "Defendants are private, for-profit companies, not subject to constitutional free speech guarantees." Id. at 631. However, it is also important to note that the Langdon court identified Google as a corporation that "uses the internet to conduct business." Id.

${ }^{144}$ The plaintiff argued that Google's service was analogous to a shopping center; however, the analogy was misplaced for the purposes of First Amendment jurisprudence. Id. at 632

145 "The Court finds unavailing Plaintiff's argument that he has no reasonable alternative to advertising on the Defendant's search engines." Id.

${ }^{146} I d$. at 632. The court also dismissed the plaintiff's Delaware free speech claim, the plaintiff's claim of fraud under Delaware law, and the plaintiff's claim of deceptive business practices under Delaware law. Id. at 632-35. The state free speech claim was dismissed because the court determined that the reaches of the Delaware Constitution are identical to the Federal Constitution; the court dismissed the fraud claim because the plaintiff failed to satisfy the intent to induce element; and finally, the court dismissed the deceptive business practice claim because, under Delaware law, there is no private right of action for deceptive business practices. Id. 
permissible unless they are rooted in several narrow exceptions. ${ }^{147}$ First, Volokh states that speech restrictions based on contract between the potential speaker and the individual subject are constitutional under Cohen v. Cowles Media. ${ }^{148}$ Second, Volokh finds little worry with regulation of speech that cuts to the heart of the commercial speech doctrine. ${ }^{149}$ Therefore, if Google's AdWords are "commercial speech," as is likely the case, then the FTC could require Google to clearly disclose that such speech was paid for, provided the speech has the propensity to deceive. ${ }^{150}$

To Volokh, and, by extension, to other First Amendment absolutists, the commercial speech doctrine is a relatively non-threatening exception to robust speech protection. ${ }^{151}$ Presumably, this exception is permissible because it is a constitutional form of consumer protection. As Volokh states, "the Court's most common definition of commercial speech is speech that explicitly or implicitly 'propose[s] a commercial transaction." "152 An advertisement seeking to induce a consumer to enter into a financial transaction in exchange for goods or services would be the classic model of commercial speech. Hypothetically, a business might say, "Our widgets are made with only onehundred percent post-consumer recycled materials." If it turns out that the widget is actually produced from one hundred percent mercury, then clearly the commercial speech doctrine would allow the FTC to forbid the company from airing this advertisement under section 5 of the Federal Trade Commission Act ${ }^{153}$ because it is likely that the consumer would suffer injury from the company's material misrepresentation. ${ }^{154}$

Volokh goes on to contrast commercial speech with situations regarding data privacy that are only tangentially related to this Comment. He states that when a corporation offers to sell information about its consumers to another interested corporation, this transaction in data cannot be constitutionally regulated under a properly framed commercial speech doctrine. ${ }^{155}$ The principle underlying this formulation of the doctrine is that such speech does not implicate

147 Volokh, supra note 24.

148 Id. at 1057 (citing Cohen v. Cowles Media, 501 U.S. 663, 669 (1991)).

149 Id. at 1079-87.

${ }^{150}$ Beneficial Corp. v. FTC, 542 F.2d 611, 617 (3d Cir. 1976).

151 See Volokh, supra note 24 , at 1079-87.

${ }^{152} I d$. at 1081.

153 See supra note 78 and accompanying text.

154 Id.

155 Volokh, supra note 24, at 1085. 
[Vol. 39:291

"fraud in a particular commercial transaction," 156 and in Volokh's view the implication of fraud is the primary justification for the regulation of commercial speech. ${ }^{157}$ This Comment argues that commonlaw fraud does not adequately protect consumers' interest in the Internet in that fraud is not intended to nor capable of correcting a market that is on the verge of monopoly. ${ }^{158}$

\section{ClassificAtion OF GOOGLE's SPONSORED RESUlts: EDITOR OR ADVERTISER?}

\section{A. Regulatory Goals in a Monopoly Market}

The regulation of advertisement under the commercial speech doctrine is a rather broadly drawn exception to First Amendment protections. The policy rests upon the notion that the corporation has far greater access to information about its goods or services than does the consumer; therefore, the corporation is situated to potentially cause harm to public heath and welfare if it engages in deceptive speech. ${ }^{159}$ Deceptive advertising poses an anticompetitive effect because it can, in a saturated market, create barriers to entry for potential competitors, such as high entry costs. The commercial speech doctrine is a method of protecting competition in the marketplace by allowing regulation of deceptive advertising.

Assume that Alex Corporation (A), a newcomer in the industry, and Bain Corporation (B), who controls seventy percent of the market-share, both produce economy-class automobiles. In order to gain a commercial advantage over $\mathrm{B}, \mathrm{A}$ decides to launch a nationwide newspaper advertising campaign. Suppose that, in an isolated incident, one of B's cars spontaneously combusted, although no one was injured. In order to capitalize on B's misfortune, A publishes photographs showing B's auto-flambé from various angles so as to create the impression that a substantial number of B's cars inevitably end up in flames. Also on the page is a statement reading “Alex's Cars Won't

156 Id. at 1082 .

157 However, under the Federal Trade Commission Act, the agency does not need to prove actual fraud to regulate the applicable industry; it need only to show that the advertising in question has the propensity to deceive. Infra note 209 and accompanying text.

158 This Comment uses the word "monopoly" not as a term of art pursuant to the law of antitrust. Instead, "monopoly" is to be understood in the context of Justice Kennedy's opinion in Turner Broadcasting. See Turner Broad. Sys. v. FCC, 512 U.S. 622, 661-62 (1994).

${ }^{159}$ Cent. Hudson Gas \& Elec. Corp. v. Pub. Serv. Comm’n, 447 U.S. 557, 564 n.6 (1980). 
Kill You." Without the commercial speech doctrine, this type of advertising would be permissible speech; further, if a private individual published the exact same treatment, the First Amendment would bar the government from regulating the information. ${ }^{160}$

A commercial enterprise understands that when it advertises, and thereby promotes a commercial transaction, it is subject to potential government regulation if the advertisement is more likely to mislead the consumer than to inform ${ }^{161}$ and if there is a likelihood of injury to the consumer. ${ }^{162}$ The commercial speech doctrine protects competition by permitting the government to regulate a direct or indirect attack on other businesses by deceiving consumers-such attacks may go beyond rigorous competition and thus become anticompetitive, especially when the actor enjoys significant market power. ${ }^{163}$ Further, FTC regulation is intended to place businesses on a somewhat equal footing when it comes to their ability to propose commercial transactions; it prevents a dominant firm from misleading consumers as to a competitor's product, an act that may harm competition by preventing or discouraging new market entry. It also places businesses on level ground, because once an FTC regulation is in place, it prohibits businesses from falling below the FTC standard, thereby protecting the communications medium itself. Given Google's significant market share and its consumer loyalty, it is not unfathomable to assume that their deceptive advertising practices may be intended to have an anticompetitive effect on the search engine market.

An obvious, yet disputed, anticompetitive effect is called "freeriding." Free-riding, in its most common form, is generally not considered to be anticompetitive because it may have a positive effect on consumer prices. However, the form of free-riding that this Comment suggests that Google is engaging in is, in many ways, the converse to the traditional free-rider model. Google is inducing advertisers to free-ride on its dominance. This is best illustrated by an example. Imagine a world where only some TV stations disclose that "the following is a paid advertisement." ${ }^{164}$ An obvious problem pre-

${ }^{160}$ See Volokh, supra note 24, at 1086 (explaining that when consumers leaflet against a shoddy developer, the leafleters are entitled to full protection under the First Amendment because their speech does not propose a commercial transaction).

${ }^{161}$ Cent. Hudson, 447 U.S. at 564.

$162 I d$.

163 See, e.g., Illinois Tool Works, Inc. v. Independent Ink, Inc, 547 U.S. 28 (2006); Eastman Kodak Co. v. Image Technical Services, Inc., 504 U.S. 451 (1992).

${ }^{164}$ This is the common disclaimer placed before an infomercial on network television because sponsorship law actually requires "broadcasters to identify those who 
[Vol. 39:291

sented by this is that consumers may assume that an infomercial, ${ }^{165}$ on a station that does not post such a disclaimer, is actually news programming ${ }^{166}$ and therefore endorsed by the station itself or at least subject to fact checking and objectivity. ${ }^{167}$ In short, the network committed the "accuracy/relevancy" substitution. Furthermore, there are downstream effects likely to affect competition. ${ }^{168}$ First, businesses will be more motivated to advertise with the network that does not post the disclaimer and therefore, by piggybacking on the goodwill of the network's news division, increase its sales through deceptive practices. ${ }^{169}$ The network will benefit from the windfall in advertising revenue, reinvest into its standard programming in an effort to increase its goodwill among viewers, and be better positioned to charge supercompetitive fees for its infomercial air space and, vis-à-vis its market power, implement barriers to entry.

In a market dominated by advertisers freeloading on the network's respectability, all the networks will likely, in an effort to remain competitive, conceptualize new ways to sell advertising in a deceptive manner. The television media would become entangled in a cut-throat race to the bottom where all providers struggle to achieve the most profitable business model, perhaps at the expense of the consumer. ${ }^{170}$ Placing economic interests above quality and accuracy will harm consumers because the variety and veracity of network programming will be reduced. Society as a whole is damaged when a speaker inculcates the gravity of his raw message with the advertising

pay for program material," and provides penalties for those broadcasters who do not. Goodman, supra note 61, at 64 (citing 47 U.S.C. $\$ \S 317(\mathrm{a})(1), 508$ (2000)) .

165 Disclosure requirements under The Communications Act of 1996 do not apply to obvious marketing such as the "traditional fifteen- or thirty-second spot advertisements, where both presence and source of sponsorship are obvious." Id. at 97.

166 This of course assumes that the advertiser is using a news-type format for its infomercial.

167 This is a classic example of what Ellen P. Goodman described as "stealth marketing." She stated, "American mass media law has long been hostile to stealth marketing. It is illegal . . . for a record company to make secret payments to radio stations to play music . . . or for an advertiser or organization to pay broadcasters to feature products . . . without identifying the sponsor." Id. at 84; $c f . i d$. at 91 (describing how sponsors "sometimes pay for 'secured placement' of their footage to achieve a kind of 'branded' journalism").

${ }^{168} I d$. at $100-04$.

169 In his article, Volokh argues that there is nothing inherently wrong with businesses taking a free ride on the work of others. Volokh, supra note 24 , at 1074 . However, Volokh addresses this problem only by proposing that giving consumers a property right in their personal information would be economically inefficient. Id. He does not address the problem freeriding presents to communications media under the commercial speech doctrine.

${ }^{170}$ Goodman, supra note 61 , at 87. 
sheen, and he becomes a mouthpiece for the "simplified operational mode." $" 171$

Dressing up an assumedly objective system, such as Google, with advertising's nebulous simplicity gravely shifts consumer expectations from accuracy to relevancy, and this shift will bleed the medium itself. Briefly outlined, the argument is as follows: consumers, initially expecting objectivity from Google yet aware of the presence of advertising, will begin to believe that everything appearing on the results page is an advertisement. Even a subtle relocation of consumer expectations creates a strong economic incentive for advertisers to continually refine their use of covert advertising methods to remain one step ahead of skeptical consumers. Ultimately, not only the message, but the Internet itself (as a medium) will suffer because it has become completely diluted with deceptive advertising. ${ }^{172}$ When consumers are unable to differentiate between advertising and information unclouded by economic incentives, ${ }^{173}$ the FTC should act to protect the channels and instrumentalities of communicationespecially when the medium is recognized as crucial to promoting the interests of a democratic society. By eliminating an advertiser's ability to piggyback on the broadcaster's reliability, the FTC protects consumers and the integrity of a complex operational mode from unscrupulously simplistic media providers.

A tension undoubtedly exists between Google's editorial freedom and the right of a sovereign to police the channels of speech. In addressing this tension, it is important to determine whether the Langdon court correctly classified Google as a newspaper editor, or whether Google is more akin to something else: a purely commercial speaker. However, the implications of characterizing Google as a newspaper or as a broadcaster do not preclude the federal government's ability to regulate Google. ${ }^{174}$ This classification is only determinative of which federal agency is best situated to promulgate rules. Because this Comment addresses only whether regulation is permis-

\footnotetext{
171 BAUDRILLARD, supra note 1.

172 Goodman, supra note 61, at 104-08 (stating that the only wholly satisfying policy justification for regulation of deceptive advertising is that "overcommercialization" will "hijack[] authentic culture and turn[] 'America's marketplace of idea's [into] . . . a junkyard of commodity ideology."”).

${ }^{173} I d$. at 110 ("The purpose of stealth marketing is to bypass audience resistance to promotional messages by giving an erroneous impression of source.").

${ }^{174}$ Even if the Langdon court was correct in extending newspaper-like editorial status to Google, the FCC could still require clear sponsorship disclosure under the Federal Communications Act of 1934. See, e.g., Langdon v. Google, Inc., 474 F. Supp. 2d 622 (D. Del. 2007)
} 
[Vol. 39:291

sible and appropriate, there is no discussion of whether the $\mathrm{FTC}^{175}$ or the $\mathrm{FCC}^{176}$ is better positioned to confront the consumer protection issue in the context of cyberspace. Further, it is important to note that this Comment assumes that application of advertising source disclosure rules will not damage discourse because the cost to Google, as a speaker and as a business, is minimal. ${ }^{177}$

\section{B. Google Is a Commercial Speaker Because Its Primary Corporate Purpose Is to Further Commercial Transactions}

This Comment adopts the rationale presented in an article by Tom Bennigson. ${ }^{178}$ His basic premise is simple: a commercial entity that is publicly traded on a national market cannot be anything other than a commercial speaker. ${ }^{179}$

In support of his argument, Bennigson first looks to the fiduciary obligations of directors and managers of a corporation. ${ }^{180}$ In American corporate law, the managers have a duty to the shareholders to increase the value of the corporation as a whole. In this respect, a shareholder may bring a derivative action challenging the decision of a manager who uses the corporate treasury for an activity constituting a breach of the duty of care or a breach of the duty of loyalty. It is the primary concern of the managers of the company to increase the value of the shareholders' stock, and any action which deviates from this premise could be considered corporate waste and therefore subject to a derivative suit for breach of the duty of care or loyalty.

This analysis begs the question of the permissible scope of the manager's decision-making abilities. The corporate manager is duty bound to increase the revenue of the corporation. In order to accomplish this task, the manager needs to induce consumers to enter

${ }^{175}$ For a discussion advocating on behalf of FTC regulation, see Sinclair, supra note 15, at 360-64 (discussing which regulatory body is best suited to regulate search engines, and concluding that the FTC is the appropriate arm of government).

176 The Federal Communications Act of 1934, 47 U.S.C. $\$ 317$ (2000) (requiring broadcast stations to disclose the identity of sponsors when any type of "valuable consideration is directly or indirectly paid or promised, charged or accepted").

177 This presumption is evidenced by the fact that disclosure regulations of broadcast radio and television did not damage speech at large. See Volokh, supra note 24, at 1112; see id. at 1052 (arguing that favoring data privacy over First Amendment absolutism will provide courts with dangerous precedent which could be used to suppress speech that was once protected but interferes with various civil rights).

178 Bennigson, supra note 84 .

179 Id. at 383.

${ }^{180}$ Id. at 393-96. 
into a financial transaction with the business. The directors' responsibility to shareholders is not without limits. As stated earlier in this Comment, a business engages in corporate speech when the purpose of the speech in question is primarily to induce a commercial transaction. ${ }^{181}$ By examining the Supreme Court's rationale for providing lesser protection for commercial speech, Bennigson concludes that commercial speech is entitled to lower scrutiny because it implicates only the speech interests of the listener-i.e., the corporate speaker's interest is not expressive. ${ }^{182}$ In determining whether speech should be considered commercial pursuant to the First Amendment, the Court looks to whether the speech is "motivated solely by the speaker's economic interests and is related to furthering commercial transactions." 183

The question thus becomes whether Google's sponsored results should be considered commercial speech. The first prong of the commercial speech analysis is whether Google's sponsored results are solely motivated by the economic interests of the corporation. ${ }^{184}$ At first blush, it seems evident that Google's AdWords program serves no other purpose than to generate revenue for shareholders. As stated earlier in this Comment, Google generated $\$ 10.6$ billion in advertising revenue in 2006. ${ }^{185}$ However, the mere fact that a category of speech is profitable should not be dispositive for a finding that the speech is commercial. ${ }^{186}$ There are several instances where a speaker may have a mere scintilla of motivation not related to economic interests. A newspaper certainly desires a profit for its efforts, however there is a clear dual purpose: newspapers also desire to be the most readable, the most erudite, or the most groundbreaking-they strive for accuracy. Google's AdWords program, by contrast, has no such secondary concerns. Their goal is to place relevant advertising-

\footnotetext{
181 Volokh, supra note 24, 1081-82.

182 In support of this argument, Bennigson cites to the recent string of cases limiting a corporation's ability to fund political campaigns. He states that because the corporation is made of stockholders, it would be illogical to assume that corporate donations represent the political voices of the individual shareholders. Bennigson, supra note 84 , at 401 . Therefore, even corporate political contributions are not fully protected under the First Amendment. Id. at 402-04. Also, under the GLIB rationale, a speech may be considered controllable if it has no expressive purpose. See Irish-American Gay, Lesbian and Bisexual Group of Boston v. Boston, 636 N.E.2d 1293, 1295-98 (Mass. 1994).

${ }^{183}$ Bennigson, supra note 84 , at 395.

184 Id. at 388 (citing Cent. Hudson Gas \& Elec. Corp. v. Pub. Serv. Comm'n, 447 U.S. 557, 561 (1980)).

185 See supra note 41 and accompanying text.

186 See Bigelow v. Virginia, 421 U.S. 809, 818 (1975).
} 
under the Hurley rationale, Google's purpose is fundamentally nonexpressive, and is not afforded full First Amendment protection. ${ }^{187}$ Therefore, the editorial content of a newspaper is substantially distinguishable from the editorial control Google asserts over its AdWords program: one strives for accuracy and the other simple relevance.

Likewise, Google does exhibit a motivation that superficially appears without economic incentives with respect to AdWords. Google seeks to provide its users with relevant information based on the keywords they enter. ${ }^{188}$ However, while it is obviously tempting to equate such relevancy with the accuracy newspapers strive to achieve, ${ }^{189}$ Google, as an advertising entity, does not retain the same societal interests as the editor of a newspaper. Google's AdWords seek to put the most relevant commercial vendor at the top of the search results list. By engaging in this practice, Google signals to potential businesses that they will get the most receptive eyes on the business's advertisements. ${ }^{190}$ At its bare essence, Google's struggle for relevancy is motivated not by a puritanical desire to accurately report on the current state of commerce, ${ }^{191}$ but rather to leverage businesses into purchasing advertising space on Google ${ }^{192}$ - this is not expressive conduct.

187 See supra notes 121-23 and accompanying text.

188 See Google.com, Welcome To AdWords, https://adwords.google.com (last visited Jan. 13, 2009) ("When people search on Google using one of your keywords, your ad may appear next to the search results. Now you're advertising to an audience that's already interested in you.").

189 See Langdon v. Google, Inc., 474 F. Supp. 2d 622, 630 (D. Del. 2007); Search King, Inc. v. Google Tech., Inc., No. CIV-02-1457, 2003 U.S. Dist. LEXIS 27193 at *12-13 (W.D. Okla. May 27, 2003).

190 Thus, Google tacitly admits that the primary purpose of AdWords is to forward it's own economic interests, thereby subjecting the AdWords program to regulation. See supra note 156 and accompanying text.

191 See Volokh, supra note 24, at 1052 (discussing how a broadened commercial speech doctrine may serve to restrict speech by consumers on economic matters). Volokh's analysis, however, is mooted by Bennigson's suggestion that courts consider both the corporation's motivation for speaking as well as the inducement requirement. See Bennigson, supra note 84, at 396.

192 This Comment recognizes that there exists a gray area as to whether the corporate speaker is motivated solely by commercial interests. Take for example a radio disc jockey that knows that when he plays certain songs it is likely that the radio station will garner more profits through advertising revenue. A situation such as this illustrates the potential dangers of examining the speaker's motivation. Fortunately for the courts, Congress drafted section 317 of the Communications Act which states that such editorial decisions may only be regulated when any type of "valuable consideration is directly or indirectly paid or promised, charged or accepted" in exchange for playing the song. 47 U.S.C. $\$ 317$ (2000). 
Google's own business plan, advertising, strongly evidences a comfortable fit within the second prong of the commercial speech analysis. ${ }^{193}$ It is clear that Google's AdWords are intended to induce the consumer into making a commercial transaction. In the first instance, Google puts eyes on the advertisements and uses this ability to attract businesses to enter into an advertising agreement with Google. ${ }^{194}$ Therefore, if a court were to require that the commercial transaction induced needs to flow directly between the consumer and the corporate speaker, this prong would be met. However, it seems that inducement into any commercial transaction would be sufficient to sustain a finding that Google's AdWords are commercial speech.

For example, in Bolger v. Youngs Drug Products Corp. ${ }^{195}$ the Supreme Court treated a condom manufacturer's informational pamphlet concerning the dangers of sexually transmitted diseases as commercial speech. ${ }^{196}$ The manufacturer argued that this was a purely informational packet designed to inform the public about the potential dangers of unprotected sexual intercourse. ${ }^{197}$ The Court found that this pamphlet was designed to induce the sexually active consumer into a commercial transaction and therefore considered the flyer commercial speech. ${ }^{198}$ Presumably, the Court does not require the benefit to actually come from the consumer directly to the corporate speaker-simply "educating" the public about STDs could increase the total volume of condom sales, thereby increasing the revenue generated by the corporate speaker.

Google's AdWords may not directly induce a commercial transaction with Google; however, the purpose of placing third-party advertising in front of potentially willing consumers certainly is intended to induce the consumer to engage in a commercial transaction with the third-party business. By increasing the visibility of advertising, Google hopes to maximize the number of sales made by the third-party advertisers and thereby increase the number of par-

193 Bennigson, supra note 84, at 396.

194 Google is currently developing Google Trends, a device that is putatively designed to assist businesses in choosing AdWords that have a high search volume. If a potential advertiser wishes to see how many searches for a term occurred within a time period and within a certain geographical area, it can do so. From that information, the advertiser can make an educated decision regarding what words to purchase. See Google Trends, http://www.google.com/trends (last visited Jan. 13, 2009).

${ }^{195}$ Bolger v. Youngs Drug Prod. Corp., 463 U.S. 60 (1983).

196 Id. at 61.

197 Id. at 62.

198 Id. at 66-67. 
[Vol. 39:291

ticipants in AdWords. Finally, an increase in AdWords sales would benefit Google by increasing revenue and ultimately the value of the shareholder's stake in the corporation. ${ }^{199}$ As shown above, this form of profit maximization may have significant anticompetitive effects, such as barriers to entry and the potential destruction of an entire market.

Free speech absolutists, who favor the holding in Langdon, argue that the First Amendment should afford newspaper-like protection to Google in order to ensure the diversity of viewpoints in the marketplace. Yet the primary justification for granting commercial speech intermediate scrutiny is to "suggest that a different degree of protection is necessary to [e]nsure that the flow of truthful and legitimate commercial information is unimpaired." ${ }^{200}$ Beyond using this statement to support the constitutionality of FTC regulation of search engines, the court's reasoning indicates that FTC regulation may further promote the commercial speech doctrine's underlying principles by ensuring that consumers have access to information which is truthful and accurate before entering into a commercial transaction. This argument assumes that there is true competition in the search engine market. However, it is evident that the search engine market is malfunctioning for several reasons. ${ }^{201}$

First, the power that search engines wield as Internet gatekeepers affords them abundantly broad discretion in imposing barriers to entry for potential speakers. This problem manifests itself in Google's AdWords program because the more necessary online advertising becomes to business success, ${ }^{202}$ the more expensive the AdWords will become. Second, customer confusion regarding whether a search result is actually sponsored exacerbates the danger of the Internet becoming nothing other than an indexed repository for advertising. In this respect, opening the door to potential federal disclosure regulation will reduce consumer confusion, and promote the

199 Sinclair's proposed regulation would not be contrary to the Supreme Court's rationale in Turner. There the Court stated that forced speech is permissible because it only limits the speaker's ability to compete in an economic market. Turner Broad. Sys. Inc. v. FCC, 512 U.S. 622, 645 (1994). In this respect, by forcing Google and other search engines to disclose their paid advertisements, the FTC would not limit Google's expression, but only its ability to reap the benefits of an anticompetive, deceptive economic scheme. See id.

${ }^{200}$ Linmark Assocs., Inc. v. Willingboro, 431 U.S. 85, 98 (1977) (citing Virginia Pharmacy Bd. v. Virginia Citizens Consumer Council, Inc., 425 U.S. 748, 771-72 (1975)).

201 See supra Part III.

${ }^{202}$ Pasquale, supra note 13, at 130-34. 
acutely democratic free speech utopia promised by early Internet advocates. Regulation of search engine advertising promotes democratic ideals by reducing entry costs for potential speakers and protecting the diversity of Internet speech. ${ }^{203}$ Finally, because Google's speech is (properly) refashioned as commercial, there is constitutional room for federal regulation, even regulation that forces Google, through narrow means, to "speak."

\section{SOLUTION: APPLYING SINCLAIR'S PROPOSAL TO CENTRAL HUDSONAND 44 LIQUORMART}

Sinclair's Comment provides an excellent framework from which to begin a discussion of regulating Google. Sinclair, undoubtedly eager to discuss potential regulation, only briefly addresses the "First Amendment . . . hurdles to the regulation of paid search engine listings" ${ }^{204}$ by stating that sponsored results are "probably exempt[] . . . from First Amendment protection." ${ }^{205}$ While Sinclair deems the commercial speech doctrine the appropriate legal portal through which the FTC could regulate Google, there are lingering difficulties. The most apparent dilemma is whether Google's actions are sufficiently deceptive to warrant an FTC rulemaking. If so, the question must become whether any FTC rule aimed at Google would survive under Central Hudson and its progeny. This section addresses both of the aforementioned issues and then considers whether regulating Google is a wise policy choice.

\section{A. FTC Regulatory Policy}

Section 5 of the Federal Trade Commission Act makes unlawful the use of deceptive acts or practices. ${ }^{206}$ While the FTC has never promulgated a single, definitive statement as to the FTC Act's warrant against deception, "[c]ertain elements undergird all deception

\footnotetext{
203 As a caveat, it is important to note that Google's AdWords program does not represent a "mixed" form of commercial and non-commercial speech. The sole purpose of the AdWords expression within the AdWords campaign is to effectuate commercial transactions with third party vendors. This is not analogous to the situation the Court faced in Nike, where the dissenting Justices reasoned that a mixed form of speech may require a delicate regulatory scheme in order to pass constitutional muster. Nike, Inc. v. Kasky, 539 U.S. 654, 676-77 (2003) (Kennedy, J., dissenting).

Sinclair, supra note 15 , at 364 .

205 Id.

20615 U.S.C. $\$ 41(\mathrm{a})(2000)$.
} 
[Vol. 39:291

cases.” ${ }^{207}$ The initial question the FTC must answer before it exercises its jurisdiction under section 5 is whether there is a practice that is likely to mislead the consumer. Under this analysis, the "entire . . . course of dealing will be considered," 208 and the inquiry is "whether the act or practice is likely to mislead, rather than whether it causes actual deception." ${ }^{209}$ Judicial analysis directly tracks the FTC's policy statement; in an interpretation of section 5, the United States Court of Appeals for the Third Circuit noted that "the likelihood or propensity of deception is the criterion by which advertising is measured." ${ }^{210}$ Since the FTC's inception, various courts have looked upon its plenary authority to regulate deceptive practices regardless of the seller's scienter. In an early opinion, the Supreme Court held that a seller's innocent mislabeling of his wood as "white pine" did not absolve liability under the FTC Act, provided that the seller's actions have a propensity to deceive consumers. ${ }^{211}$ In so holding, the Court noted that "competition may be unfair within the meaning of this statute and within the scope of the discretionary powers conferred on the [FTC], though the practice condemned does not amount to fraud as understood in [common law].."${ }^{212}$

Case law and the FTC's own policy statements verify the proposition that the seller's intent is irrelevant to deception. Abundant case law indicates that proof of actual deception is not necessary, but may be sufficient, under the FTC Act. ${ }^{213}$ Case law also labels section 5 as a prophylactic measure against deception. ${ }^{214}$ So long as the consumer is likely to be deceived by an entire course of dealing, the FTC possesses the authority to impose consumer protection regulation. ${ }^{215}$ In many instances however, the FTC is positioned to provide actual evi-

${ }^{207}$ Hon. Bob Packwood, Federal Trade Commission, FTC Policy Statement on Deception, reprinted in Dee Pridgen \& Richard M. Alderman, Consumer Protection \& THE LAW 826 (2007).

208 Id. at 828 .

209 Id.

${ }^{210}$ Beneficial Corp. v. FTC, 542 F.2d 611, 617 (3d Cir. 1976).

211 FTC v. Algoma Lumber Co., 291 U.S. 67, 81 (1934).

212 Id.

213 See Chrysler Corp. v. FTC, 561 F.2d 357, 363 (D.C. Cir. 1977); U.S. Retail Credit Ass'n v. FTC, 300 F.2d 212, 221 (4th Cir. 1962); Bockenstette v. FTC, 134 F.2d 369, 371 (10th Cir. 1943); In re Cliffdale Assoc., Inc., 103 F.T.C. 110 (1984).

${ }^{214}$ FTC v. Sterling Drug, Inc., 317 F.2d 699, 674 (2d Cir. 1963).

215 The policy rationale for judicial acquiescence to FTC regulation in the absence of evidence of actual confusion is two-fold. First, the courts defer to the expertise of the administrative body. Pridgen \& Alderman, supra note 207, at 770. Second, imposing a requirement of proof of actual consumer confusion would be "costly and inefficient." Id. 
dence of consumer deception. In a survey of case law, Pridgen and Alderman demonstrate that courts routinely uphold FTC regulation when between thirteen and twenty percent of consumers were actually mislead by the advertiser's conduct. ${ }^{216}$

At the current time, it is impossible to gauge with sufficient accuracy the exact percentage of Google users who are deceived into clicking on advertisements. The most accurate estimate of deception originates in the Pew study. ${ }^{217}$ Pew found that one out of six, or roughly seventeen percent, of Internet search engine users are unable to distinguish between sponsored and organic results. ${ }^{218}$ Given the empirical data, it appears that the FTC would be free to regulate pursuant to a showing of actual consumer deception. ${ }^{219}$ Under the "entire course of dealing" analysis, the FTC could easily find that Google is likely to mislead consumers into thinking that sponsored results are accurate, organic results.

On January 18, 2009, a Google search for "shoes" revealed that the search results yield a likelihood of deception. Google does not spatially separate three sponsored results from the organic results. Google does make an effort to distinguish between the two, but this half-hearted attempt does not cure the results page of its deceptive nature. The first three results are positioned directly above the organic results; the typeface is identical as between the two; and while "sponsored result" does appear in the vicinity of the advertisements, the color discreetly blends into the background and is almost imperceptible to a reasonable user. ${ }^{220}$ Further, the term "sponsored results" is placed on a separate visual plane from the results themselves. Even the term "sponsored results" does not necessarily indicate that the results are paid for: the first definition of the verb "to sponsor" is, "promise, vouch, or answer for." 221 Google hardly "vouches" for the AdWords participants, in fact, as shown in American Blind, Google dis-

216 PRIDGEN \& Alderman, supra note 207, at 771 (citing In re Benrus Watch Co., 352 F.2d 313 (8th Cir. 1965); See In re Book of the Month Club, 202 F.2d 486 (2d Cir. 1952)).

217 FaLlows, supra note 3.

218 Id. at 17.

219 The Pew Study's seventeen percent number may actually be underinclusive because it only addresses the number of people who are unaware of search engine's practice of including sponsored results. Their data does not incorporate the portion of the public who are aware of the practice, but unaware of where those results appear.

${ }^{220}$ The reasonable consumer is the modern guidepost for judicial analysis of an FTC finding of deception. PRIDGEN \& Alderman, supra note 207, at 777-81.

221 WEBSTER's, supra note 70, at 1843. 
[Vol. 39:291

tances itself from its advertisers. ${ }^{222}$ Distancing oneself from his copy is not consistent with the actions of a newspaper editor, who traditionally stands by (vouches for) his stories. Therefore, Google, by its own actions, acts not like a newspaper editor but like a disinterested compiler of advertisements, and full First Amendment protection is unwarranted and unnecessary. Regardless of whether the FTC chooses to present direct evidence of deception, or whether they proceed with their discretionary authority to regulate under the "likely to deceive" doctrine, the FTC could confidently assert jurisdiction over Google. ${ }^{223}$

Another framework under which the FTC could pursue regulation of Google is the deception by omission analysis. In order for an omission to be misleading the speaker must omit a material fact. ${ }^{224}$ As stated by Pridgen and Alderman, omissions may arise from the "ordinary consumer's assumptions about a product that are simply not corrected by the advertisement." ${ }^{225}$ The closest test for materiality under the FTC act appears in 15 U.S.C. $\$ 55$ (a) (1), which states that an omission is material if "the extent to which the advertisement fails to reveal facts material in the light of such representations or material with respect to consequences which may result . . . under such conditions as are customary or usual." ${ }^{226}$ The FTC has illuminated various instances where there is a presumption of deception by omission. The most pertinent for Google is the presumption of deception that is created when there is an omission as to the nature of the product.

The FTC and the courts have construed deception as to the "nature of the product" quite liberally. A non-exhaustive list of various rules concerning nature of the product deception includes labeling as to the size of sleeping bags, ${ }^{227}$ labeling indicating that a seat belt is not actually composed of leather, ${ }^{228}$ labeling as to the length of an extended ladder, ${ }^{229}$ and labeling disclosing the size of a tablecloth. ${ }^{230}$ By

${ }^{222}$ Google, Inc. v. American Blind \& Wallpaper Factory, Inc., C-03-5340, 2007 U.S. Dist. LEXIS 32450, *8 (N.D. Cal. Apr. 18, 2007)

${ }^{223}$ FTC findings of deception are sufficient for the agency to exert regulation over an advertiser. See supra note 216 and accompanying text. "Moreover, uncontradicted evidence of experts or consumers that there was no actual deception in particular cases has been deemed insufficient to overcome the Commission's conclusion that there was a tendency or capacity to deceive." PRIDGEN \& ALDERMAN, supra note 207, at 771 .

${ }^{224}$ J.B. Williams Co. v. FTC, 381 F.2d 36 (D.C. Cir. 1950).

225 PRIDGEN \& ALDERMAN, supra note 207, at 880-81.

${ }^{226} 15$ U.S.C. $\$ 55(\mathrm{a})(1)(2000)$.

227 16 C.F.R. $\$ 400$ (1985).

228 Id. $\$ 405$.

229 Id. $\$ 481$. 
analogy, the aforementioned regulations are miniscule in potential detriment to the consumer when compared to Google's failure to adequately disclose which search results are sponsored. ${ }^{231}$ Finally, each of these regulations could be characterized as forced speech. Such regulation would be unconstitutional but for the fact that the rule is imposed upon a commercial speaker. Having already established that Google's AdWords program is best classified as commercial speech, ${ }^{232}$ the next analytical step is to examine whether requiring Google to "label" its search engine results would survive a Constitutional challenge under the commercial speech doctrine.

\section{B. Eliminating Restraints on Competition Is Always a Substantial Governmental Interest}

Sinclair proposes a three-fold regulation requiring search engines to make clear disclosures of its sponsored results. First, Sinclair suggested that search engines should be required to clearly state that sponsored results are "paid listings." ${ }^{233}$ Second, paid listings should be colorfully and spatially separated from unpaid listings. ${ }^{234}$ Finally, paid listings should have at least one other identifiable difference from unpaid listings. ${ }^{235}$ Should the FTC choose to promulgate and enforce similar disclosure rules upon search engines, this section seeks to provide the agency with the legal doctrine upon which it may rely.

Turning toward the Central Hudson framework, the Unites States Supreme Court in that case addressed the issue of whether the New York Public Service Commission (Commission) violated the First and Fourteenth Amendment by completely banning promotional advertising by an electrical utility (Utility). ${ }^{236}$ In 1973, the State of New York faced a severe energy shortage, and sought to address the issue by limiting a Utility's ability to induce consumers into purchasing electrical services-" [a]ny increase in demand for electricity . . . means greater consumption of energy." ${ }^{237}$ In confronting this question, the Court applied a four-factor test to determine whether the

${ }^{230} I d . \S 404$.

231 See supra text accompanying notes 159-71.

232 Supra Part IV.

233 See supra note 79 and accompanying text.

234 See supra note 80 and accompanying text.

235 See supra note 81 and accompanying text.

${ }^{236}$ Cent. Hudson Gas \& Elec. Corp. v. Pub. Serv. Comm., 447 U.S. 557, 558 (1980).

237 Id. at 568 . 
[Vol. 39:291

Commission's regulation of advertising passed constitutional muster. $^{238}$ By applying the "commonsense" distinction between speech "proposing a commercial transaction . . . and other varieties of speech" ${ }^{239}$ which assumedly provide the speaker with more, or perhaps less, constitutional protection, the Court concluded that the Utility's advertising proposed a commercial transaction. ${ }^{240}$

The Court reasoned that for speech proposing a commercial transaction to merit First Amendment protection, it must neither concern unlawful activity nor be misleading. ${ }^{241}$ Second, the Court must determine "whether the asserted governmental interest is substantial." ${ }^{242}$ Third, if the answers to the foregoing questions "yield positive answers," ${ }^{243}$ then the Court will address whether "the regulation directly advances the governmental interest asserted." ${ }^{44}$ Finally, the Court must assess whether the regulation is "not more extensive than is necessary to serve that interest." 245

The threshold issue for Google would be whether Google's speech-its "opinion" on a matter of public concern materialized as placing advertising on its search page-is misleading. There is an astonishing absence of case law that upholds a speech restriction because the commercial speech in question was misleading. However, there is at least a compelling argument that Google's AdWords are misleading. While it is easy to conceptualize a situation where an advertiser can mislead by making blatantly false statements in its advertising campaign, the argument becomes more nuanced-and perhaps too tenuous-in the context of Google's AdWords. The FTC would have to argue that Google, by not clearly delineating between its sponsored results and its organic results, misleads consumers of the third party product. This argument is thin because Google is not the actual advertiser, even though its speech is commercial. Google's status as a commercial speaker in this instance does not arise through its own advertising campaign; it arises because Google supplies editorial control over the advertising of others. This fact makes it difficult to characterize Google's speech as more likely to be misleading than informative. Thus, Google's speech is likely misleading for the pur-

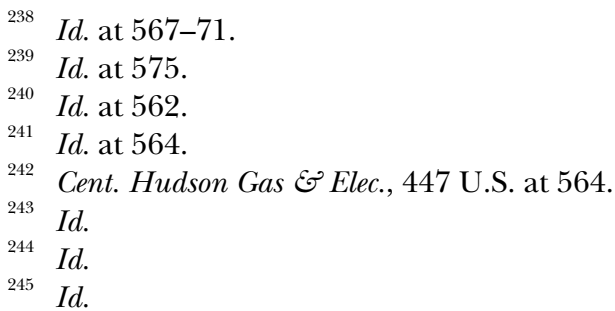


poses of section 5 of the FTC Act, but it is not "misleading" within the context of a rigorous Central Hudson analysis, which, if satisfied, would allow regulation of the speech provided there is a rational basis. ${ }^{246}$ While Google's AdWords may have a propensity to deceive under the FTC Act, it is unlikely to be "misleading" under Central Hudson. Further, there is no indication whatsoever that AdWords concerns illegal activity. Therefore, Google's AdWords is entitled to some form of First Amendment protection, requiring the reviewing court to next inquire whether the asserted government action is substantial.

In determining substantiality, a court could easily analogize Google's speech to Turner Broadcasting ${ }^{247}$ where the Supreme Court found the following important governmental interests: "(1) [p]reserving the benefits of free, over-the-air local broadcast television, (2) promoting the widespread dissemination of information from a multiplicity of sources, and (3) promoting fair competition in the market for television programming." ${ }^{248}$ Likewise, "[t]he judgment of the legislative branch cannot be ignored or undervalued simply because [those sought to be regulated] casts its claims under the umbrella of the First Amendment." ${ }^{249}$ Under Turner the Court further reasoned that "assuring that the public has access to a multiplicity of information sources is a governmental purpose of the highest order." ${ }^{250}$ As shown in Part I of this Comment, by empirical data, and by various other commentators, the search engine market teeters on monopoly at the most serious end of the spectrum, or is a clearly actualized oligopoly at best. Indeed, "the Government's interest in eliminating restraints on fair competition is always substantial, even when the individuals or entities subject to particular regulations are engaged in expressive activity protected by the First Amendment." ${ }^{251}$ Regardless of whether a reviewing court justifies FTC regulation under an economic or an informational rationale, the Government likely has a substantial interest in regulating Google's AdWords program.

The next inquiry pursuant to Central Hudson is whether FTC regulation of AdWords directly advances the Government's interest in protecting fair competition in a market whose commodity is speech. The appropriate test is whether the proposed regulation will

246 Id.

247 Turner Broad. Sys., Inc. v. FCC, 512 U.S. 622, 662 (1994).

$248 \mathrm{Id}$.

249 Columbia Broad. Sys. v. Democratic Nat'l Comm., 412 U.S. 94, 103 (1973).

250 Turner Broad., 512 U.S. at 663. added).

Id. (citing Lorain Journal Co. v. United States, 324 U.S. 143 (1951)) (emphasis 
[Vol. 39:291

advance the Government's goal to "a material degree." ${ }^{252}$ In defining Rhode Island's evidentiary burden, the Court determined that when defending a regulation limiting lawful and truthful liquor price advertising, the state must show the "advertising ban will significantly reduce alcohol consumption." ${ }^{253}$ Rhode Island was unsuccessful in showing that banning liquor advertisements containing price would "mitigate competition and maintain prices at a higher level than would prevail in a completely free market." ${ }^{254}$ While the Court noted that the state's justification was a reasonable assumption with which it agreed, the state failed to meet its evidentiary burden in proving the assumption. ${ }^{255}$

Further, 44 Liquormart struck down a ban on commercial speech because "bans against truthful, nonmisleading commercial speech . . . usually rest solely on the offensive assumption that the public will respond 'irrationally' to the truth. ${ }^{256}$ Google's AdWords program is distinguishable from the ban in 44 Liquormart because the FTC would not regulate on the assumption that the public is incapable of rationally responding to the truth. Quite to the contrary, by forcing Google to disclose sponsored results the Government seeks not to protect consumers from themselves, but to protect consumers from potentially exploitative advertising practices. The presupposition that Google would potentially give the wrong impression as to the relevancy of its search results is far more palatable from a First Amendment perspective than the assumption that consumers are fundamentally irrational.

The question therefore becomes whether forcing Google to make unambiguous disclosures of sponsorship within its search results will significantly reduce consumer confusion. The FTC must also show that a reduction in consumer confusion will protect fair competition in the search engine market by ensuring "widespread dissemination of information from a multiplicity of sources." ${ }^{257}$

As indicated by the Pew Study, one out of every six Internet search engine users are unable to distinguish between sponsored and non-sponsored results. ${ }^{258}$ In every instance where a consumer clicks on a sponsored result thinking it is an objectively accurate result, the

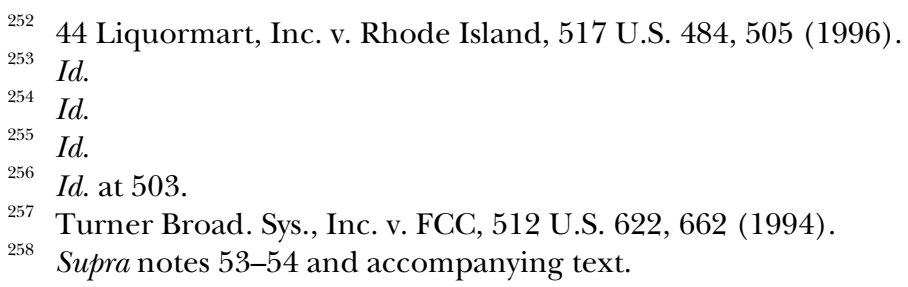


user is confused and misled by the advertisement. A complete disclosure of result sponsorship will significantly reduce the aggregate amount of confusion, ${ }^{259}$ and will likely eliminate confusion amongst consumers who are unable to differentiate between Google's advertising machine and its organic results. The question of whether this reduction in confusion is substantial will likely turn on an issue of fact. But given the substantial number of bewildered searchers, a reduction by disclosure is likely significant either in the aggregate or on an individual basis; however, as this is a question of empirics, it requires further study.

The connection between reduction in the amount of consumer confusion and the government's interest in ensuring widespread dissemination of information from a variety of sources is best illustrated by a hypothetical. Suppose Judovin LLC (J) and Goldberg Corporation $(G)$ are both engaged in the sale of handmade soaps, and both solely do business on the Internet. G manufactures an astonishing variety of soaps, but at a lower quality than $\mathrm{J}$, who manufactures the finest organic lavender soap in the land. G, an organization of dubious ethics, purchases, among other things, the following AdWords: "handmade lavender soap," and "Judovin." J does not purchase AdWords. Under the current regime, for a consumer who enters the search terms "Judovin" and "handmade soap" or "lavender," the first result on Google would be a link to G's webpage, and a consumer who expects to purchase high quality $\mathrm{J}$ soap will be presented with the option to purchase lower quality and lower priced G soap. ${ }^{260}$ Because the consumer did not receive the information he sought, he may never have the opportunity to make an informed choice as to the soap he ultimately purchases. Furthermore, $\mathrm{G}$ may have the ability to charge supercompetitive prices or prevent new market entry through its use of AdWords and the concomitant reverse free-riding rational

${ }^{259}$ The aggregate confusion is reduced by the ratio of the sum of the number of users who cannot distinguish sponsored results and the number of times each confused user is misled by the sponsored results to the overall volume of search engine use.

${ }^{260}$ While there may be a trademark remedy for initial interest confusion on the set of facts as presented, the issue is as of yet undecided. See, e.g., Google, Inc. v. American Blind \& Wallpaper Factory, Inc., C-03-5340, 2007 U.S. Dist. LEXIS 32450, *8 (N.D. Cal. Apr. 18, 2007). Because Judovin is likely a generic mark, this Comment assumes the mark has not achieved the secondary meaning necessary to warrant trademark protection, and the trademark issue is therefore moot. Even if a trademark remedy were available, such a remedy would merely represent piecemeal gapfilling and would only protect the interests of the trademark holder. Likewise, a trademark remedy does not provide predictable consumer protection, nor would it forward the Government's interest in ensuring a diversity of information. 
[Vol. 39:291

described above. ${ }^{261}$ While the aforementioned micro-scenario is clearly whimsical, the impact such practice would have on a macro level is significant and ultimately beyond the FTG's current regulatory reach. ${ }^{262}$ Requiring clear disclosure of sponsored results will reduce consumer confusion and, by giving consumers the ability to make an informed choice as to whether they wish to view advertising or objectively reliable results, thereby ensure diversity of information and protect a market whose commodity is speech.

The final inquiry under Central Hudson is whether the proposed regulation is not more extensive than is necessary. The only way for the government to forward its substantial interest in reducing consumer confusion and promoting a diversity of information is to require sponsorship disclosure. One arena where regulation by forced disclosure served to ensure diversity of information is the payola scandal of the 1950's. ${ }^{263}$ In response to the practice of radio stations accepting money from artists to play their songs on the air, Congress enacted 47 U.S.C. $§ 317,{ }^{264}$ which states:

all matter broadcast by any radio station for which any money, service or other valuable consideration is directly or indirectly paid, or promised to or charged or accepted by, the station so broadcasting, from any person, shall, at the time the same is so broadcast, be announced as paid for or furnished, as the case may be, by such person. ${ }^{265}$

The rationale for this legislation was to decrease barriers for new artists wishing access to the radio. ${ }^{266}$ By attempting to ensure objective popularity as the benchmark for radio play, Congress protected consumer's rights to hear a diversity of music. The assumption upon which $\S 317$ rests is that the only way consumers will know they are being presented with sponsored material is to require the recipient of the consideration to disclose the transaction to the consumers. ${ }^{267}$

261 See supra notes 159-71 and accompanying text.

262 Section 5 of the Federal Trade Commission Act grants the FTC authority to regulate unfair and deceptive acts. 15 U.S.C. $\$ 45(1)$ (2000). While the FTC may have a course of action against G, under the current state of affairs the FTC would not be able to limit Google's ability to sell AdWords to predatory purchasers because Google is not in competition with G. See id.

${ }^{263}$ See generally Bracha \& Pasquale, supra note 26 (offering a discussion of potential Federal Communications Commission jurisdiction over Google).

26447 U.S.C. $\$ 317$ (a) (1) (2000).

265 Id.

${ }^{266}$ Sarah Greene, Legislative Update: Clear Channel v. Competition Act of 2002: Is There a Clear End in Sight?, 12 DePAul-LCA J. ART \& ENT. L. \& POL'y 387, 426 (2002).

${ }^{267}$ See In re Nat'l Broad. Co., 27 F.C.C. 2d 75, 75 (1970) ("The purpose of Section 317 of the Act . . . is to require that the audience be clearly informed that it is hear- 
In an auditory medium, requiring the disc jockey to announce that a certain song was paid for is the only way to communicate the necessary information to consumers. Google's results page, being a visual medium, requires a far more difficult and nuanced solution to the problem of whether the regulation is more expansive than is necessary. Are differences in color between organic and sponsored results sufficient to alert consumers? ${ }^{268}$ Is color in combination with "paid listing" effective? ${ }^{269}$ Would the requirement of a discretionary third category adequately inform consumers that their results are merely advertising? There are no clear answers without a scientific study that finds the balance between what is necessary to promote diversity of information and what is unconstitutional forced speech. This Comment, while advocating for Governmental regulation of search engine practices, therefore cautions the FTC to conduct a consumer study before exacting any rules upon Google.

\section{Is Regulating Google a Wise Policy Choice?}

Even though the FTC possesses regulatory jurisdiction over Google's deceptive practices and such governance is not constitutionally impermissible, FTC rules may nonetheless be an unwise policy choice. This Comment, even if it could, seeks to do no harm to Google. Google is a tremendous business, which operates at the forefront of technology and provides the public with an invaluable service. Google is not evil; to the contrary, it is generally beneficent. For example, it provides its programmers with the funding necessary to carry out the programmers' personal projects and requires that twenty percent of the programmer's time be devoted to individual, non-Google projects. ${ }^{270}$ This Comment does however assert that Google occupies a critical seat in our society. Much to humanity's dismay, Google is ultimately a business that potentially harbors objectives and incentives antithetical to the common good. FTC regulation of Google's AdWords would not undermine the service Google provides; it would enhance and affirm the sacrosanct societal values of free speech, informational reliability, and free-market enterprise.

ing or viewing matter which has been paid for, when such is the case, and that the person paying for the broadcast of the matter be clearly identified.").

268 This question is most likely answered in the negative as Google currently and voluntarily uses color to distinguish between categories of results, yet consumers are still confused.

269 Again, Google voluntarily uses spatial and textual devices to distinguish, yet confusion abounds.

${ }^{270}$ Stephen Baker, Google and the Wisdom of Clouds, Business WeEk, Dec. 13, 2007, at 32 . 
[Vol. 39:291

Nor would FTC regulation decrease Google's economic value. With their deftness at placing Internet advertising, requiring the entire search engine market to clearly disclose sponsored results will not turn advertisers away from Google. The regulation will protect the information market from slipping into a reality mitigated by advertising-the simplified operational mode. We should demand complexity, accuracy, and fair competition in our speech markets. However, there is currently insufficient data that would indicate a present need for immediate action. Future regulation is undoubtedly prudent, but hasty action may lead to unintended consequences. The greatest disservice the government could do to our informational nodes is regulate them into oblivion. Without a profit, there is no incentive to provide the service. While the requirement of clear disclosure is only a small step towards ensuring informational diversity and autonomy, the FTC should remember that discretion is sometimes the better part of valor-but it only took one day for the Library of Alexandria to burn to the ground.

\section{CONCLUSION}

The Internet has the potential to be what our collective unconscious imagined: a truly democratic society that satisfies niche market consumers and mainstream tastes alike. However, the First Amendment assumption that the only way to promote a democracy is by permitting speakers unfettered editorial control dissipates in the online arena. While we should not abandon this assumption through piecemeal First Amendment exceptions, we should thoughtfully apply existing doctrine to new modes of speech. The Google gatekeeper, motivated purely by economic interests, should not have unregulated control and exclusionary power over our age's most precious nodes of communication. Conversely, Internet consumers, at times both naïve and loyal, are susceptible to confusing "relevancy" with "accuracy," especially when misled by the Google advertising machine. Further, this confusion may lead to an unknown and unknowable decline in the quality of information presented to information consumers. Regulation of Google's deceptive advertising practices will increase the relevance of search results and thereby ensure that searchers are more likely than not to find what they are looking for. As a society dependent on the Internet for making decisions from the most trivial to the most pivotal, we must demand relevance in search engine results. By encouraging responsible behavior from those entities that dominate and disseminate the information upon 
which we all rely, we ensure diversity, dependability, and protect the Internet from re-forming itself into a simplified operational mode. 